\title{
DID ROBERT BORK UNDERSTATE THE COMPETITIVE IMPACT OF MERGERS? EVIDENCE FROM CONSUMMATED MERGERS
}

\author{
Orley C. Ashenfelter \\ Daniel Hosken \\ Matthew C. Weinberg \\ Working Paper 19939 \\ http://www.nber.org/papers/w19939 \\ NATIONAL BUREAU OF ECONOMIC RESEARCH \\ 1050 Massachusetts Avenue \\ Cambridge, MA 02138 \\ February 2014
}

The views expressed in this article are those of the authors and do not necessarily represent those of the Federal Trade Commission or the National Bureau of Economic Research. We are grateful for financial support from the Industrial Relations Section, Princeton University. We would like to thank Pauline Ippolito and Paul Pautler for their assistance, and Dennis Carlton and Sam Peltzman for helpful comments and suggestions.

NBER working papers are circulated for discussion and comment purposes. They have not been peerreviewed or been subject to the review by the NBER Board of Directors that accompanies official NBER publications.

(C) 2014 by Orley C. Ashenfelter, Daniel Hosken, and Matthew C. Weinberg. All rights reserved. Short sections of text, not to exceed two paragraphs, may be quoted without explicit permission provided that full credit, including $(\mathcal{C}$ notice, is given to the source. 
Did Robert Bork Understate the Competitive Impact of Mergers? Evidence from Consummated Mergers

Orley C. Ashenfelter, Daniel Hosken, and Matthew C. Weinberg

NBER Working Paper No. 19939

February 2014

JEL No. K21,L1,L4,L41

\begin{abstract}
In The Antitrust Paradox, Robert Bork viewed most mergers as either competitively neutral or efficiency enhancing. In his view, only mergers creating a dominant firm or monopoly were likely to harm consumers. Bork was especially skeptical of oligopoly concerns resulting from mergers. In this paper, we provide a critique of Bork's views on merger policy from The Antitrust Paradox. Many of Bork's recommendations have been implemented over time and have improved merger analysis. Bork's proposed horizontal merger policy, however, was too permissive. In particular, the empirical record shows that mergers in oligopolistic markets can raise consumer prices.
\end{abstract}

Orley C. Ashenfelter

Industrial Relations Section

Firestone Library

Princeton University

Princeton, NJ 08544

and NBER

c6789@princeton.edu

Daniel Hosken

Federal Trade Commission

600 Pennsylvania Avenue, NW

Washington, DC 20580

dhosken@ftc.gov

\author{
Matthew C. Weinberg \\ Department of Economics \\ Drexel University \\ 3600 Market St, 7th Floor \\ Philadelphia, PA 19104 \\ mcw325@drexel.edu
}




\section{Introduction}

Merger enforcement by the U.S. Department of Justice (DOJ) and the U.S. Federal Trade Commission (FTC) was extremely aggressive in the 1950s, 1960s, and early 1970s. In The Antitrust Paradox Robert Bork argued that U.S. courts and antitrust enforcers of this era were concerned about the consolidation of economic decision making in the hands of a relatively small number of corporations and the corresponding decline in the economic importance of small independent businesses. ${ }^{1}$ As a result, U.S. merger policy was focused on maintaining low levels of market concentration rather than determining how specific mergers would change the competitive environment in a market. While courts sometimes acknowledged that mergers could generate efficiencies, efficiencies were not seen as being sufficient to overturn the competitive concerns caused by increased market concentration. ${ }^{2}$ Moreover, during this time period the government was remarkably successful in challenging mergers. In Von’s Grocery, the Supreme Court affirmed the FTC's decision to challenge the merger of two Los Angeles grocery retailers with a combined market share of only $7.5 \%$. In summarizing the (then) Supreme Court's view of horizontal merger policy, Justice Stewart wrote in his dissent to Von’s Grocery that “The sole consistency that I can find is that in litigation under Section 7, the Government always wins.”

By the late 1980s, the burden of proof required of the U.S. antitrust agencies to challenge horizontal mergers had dramatically increased. ${ }^{3}$ Establishing that a merger would increase market concentration in a well-defined market became the starting place for horizontal merger analysis rather than the end point. To successfully challenge a merger, the government was

\footnotetext{
${ }^{1}$ The Antitrust Paradox, pages 202-205.

${ }^{2}$ For example, the Supreme Court majority opinion in FTC vs. Proctor and Gamble stated that, "Possible economies cannot be used as a defense to illegality. Congress was aware that some mergers which lessen competition may also result in economies but it struck the balance in favor of protecting competition.”

${ }^{3}$ Kovacic (2003) provides an excellent discussion of the dramatic changes in merger policy and case law that took place between the 1960s and 1980s.
} 
required to provide the court with an economic theory that described how the transaction at issue would harm competition and extensive evidence supporting its theory. In addition, the government was now forced to show that market forces, such as expansion by rivals or the entry of new firms, would not be sufficient to maintain competition following a potentially anticompetitive merger. Finally, beginning with the 1984 revision of the Merger Guidelines, the U.S. antitrust agencies formally acknowledged that mergers can generate important economic efficiencies. While the burden was on the merging parties to show that reductions in marginal costs resulting from the merger would offset the merged firms' incentive to increase price, the government was now required to rebut an efficiency defense.

This increase in the evidentiary burden placed on the government has substantially limited its ability to challenge horizontal mergers. A series of major government losses of merger cases has led some scholars to conclude that the burden placed on the government is now too severe (Baker and Shapiro (2009)). The government no longer always wins.

Robert Bork’s The Antitrust Paradox played an important role in moving horizontal merger policy from its strict emphasis on market concentration to its current application as seen in both the modern case law and the Horizontal Merger Guidelines. In The Antitrust Paradox Bork challenges the logic underlying many prominent merger decisions, and more generally, the (then) commonly held beliefs underlying merger policy. He felt that most mergers were either competitively neutral or undertaken to generate economic efficiencies. Because mergers were frequently socially beneficial, Bork believed that merger policy should be much more permissive than it was in the 1960s and 1970s. While he conceded that some mergers could generate market power, Bork believed those problematic cases were limited to the creation of either a monopoly 
or a dominant firm. Bork was especially skeptical that mergers could create or exacerbate competitive harm in oligopolistic markets.

While we agree with some of Bork’s critique of merger enforcement circa 1970, we believe Bork went too far in dismissing likely competitive harm resulting from mergers that fell short of creating a monopoly or dominant firm. Subsequent empirical studies examining the price effects of consummated mergers have shown that, contrary to what Bork believed, mergers in oligopolistic markets can increase prices.

The goal of this essay is to evaluate how well the claims Bork made regarding mergers in The Antitrust Paradox are supported by the current empirical record. To offer a fair criticism of Bork, however, it is essential to acknowledge how much antitrust analysis generally, and horizontal merger policy in particular, has changed since the publication of The Antitrust Paradox. Thus, we begin by briefly describing the U.S. merger policy that Bork was responding to by highlighting two key Supreme Court decisions from the 1960s: U.S. vs. Von’s Grocery and FTC vs. Proctor and Gamble. We then discuss Bork’s critique of merger policy and his suggestions for improvements. Next, we describe the dramatic changes in horizontal merger policy that followed the publication of The Antitrust Paradox, because these changes resulted in a very different composition of mergers both allowed and challenged by U.S. antitrust authorities. Finally, we turn to our review of ex-post merger studies to evaluate Bork’s predictions regarding how mergers in oligopoly markets have affected competition and the importance of merger efficiencies.

\section{Merger Policy Prior to The Antitrust Paradox}

U.S. antitrust authorities were very concerned with the growth of large corporations, and believed that the diminished role of smaller firms in industries would harm competition. As a 
result of this concern, antitrust authorities aggressively challenged both mergers that increased market concentration and expansion by large firms into adjacent markets. The Von's Grocery case exemplifies both the aggressiveness of horizontal merger policy and its focus on market concentration during this era. In 1960, Von's Grocery, a supermarket chain operating in the greater Los Angeles area, purchased a rival chain, Shopping Bag Food Stores. At the time of the merger, Von's Grocery and Shopping Bag Food Stores had a combined market share of 7.5\% of grocery sales in Los Angeles, and the ten largest firms had a collective market share of roughly $50 \% .{ }^{4}$ The FTC claimed that the merger would harm competition by increasing market concentration in a market undergoing rapid consolidation, and sued to block the transaction. The District Court denied the FTC’s request to block the merger, and Von's acquired Shopping Bag Food Stores. ${ }^{5}$ The case was ultimately appealed to the U.S. Supreme Court which reversed the District Court's decision and forced Von's to divest the stores it acquired in 1966.

Surprisingly, the majority opinion does not cite evidence showing that the merger of Von's and Shopping Bag created or enhanced market power despite hearing the case six years after the merger was consummated. ${ }^{6}$ Instead, in concluding its decision the Court stated that, "It is enough for us that Congress feared that a market marked at the same time by both a continuous decline in the number of small businesses and a large number of mergers would slowly but inevitably gravitate from a market of many small competitors to one dominated by one or a few giants, and competition would thereby be destroyed.” The emphasis on market concentration and concerns of growing concentration in determining which horizontal mergers are likely to

\footnotetext{
${ }^{4}$ By modern terms, this market does not appear very concentrated. Ellickson (2007) reported that in 1998 the top 6 supermarket retailers in the average U.S. market captured about $70 \%$ of industry sales.

${ }^{5}$ United States v. Vons Grocery Co.

${ }^{6}$ Justice Stewart noted in his dissenting opinion that, "There is simply no evidence in the record, and the Court makes no attempt to demonstrate that the increment in market share obtained by the combined stores can be equated with an increase in the market power of the combined firm.”
} 
cause competitive problems were formalized in the first edition of the Merger Guidelines published by the DOJ in 1968. In stating its "General Enforcement Policy” the DOJ stated that, “the primary role of Section 7 enforcement is to preserve and promote market structures conducive to competition." ${ }^{7}$ The Guidelines implemented this policy by providing very explicit market share thresholds that would likely generate enforcement action by the agency. For example, in a highly concentrated market (defined as one where the top 4 firms amount to more than $75 \%$ of sales), the DOJ stated it would "ordinarily challenge” the merger of two firms each with a 4\% market share, and that in markets with a "trend toward concentration" the Department will ordinarily challenge any acquisition by “any firm who’s market share amounts to $2 \%$ or more.",

Regulators and courts were also concerned that mergers could provide firms with a cost advantage relative to rivals. Perhaps, the most famous example of this concern can be seen in the Supreme Court's 1967 decision in FTC v. Proctor and Gamble (often referred to as the Clorox case). In the 1950s Proctor and Gamble (P\&G) was a very successful manufacturer and marketer of home cleaning products including laundry detergents. However, it did not manufacturer or market a bleach product. In 1957, P\&G choose to enter the liquid bleach business by purchasing the Clorox Chemical Company, the owner of the most popular bleach brand in the U.S., Clorox. The FTC sued to break up the merger arguing that P\&G's acquisition "might substantially lessen competition or tend to create a monopoly in the production and sale of household liquid bleaches.” This merger was not challenged because of a traditional vertical or horizontal concern. Instead, the FTC described this merger as a "product-extension” merger. It was concerned that because $P \& G$ was such a powerful producer of products complementary to

\footnotetext{
${ }^{7} 1968$ Merger Guidelines, Horizontal Mergers, Sections 2.

81968 Merger Guidelines, Horizontal Mergers, Sections 5 and 7.
} 
bleach, that the merger would cause the bleach market to become less competitive. The FTC won an administrative trial and ordered $P \& G$ to divest Clorox. The Court of Appeals reversed the FTC's decision, but on further appeal the Supreme Court the court ruled in favor of the FTC and forced $\mathrm{P} \& \mathrm{G}$ to divest Clorox.

The court cited two primary reasons for challenging the merger. First, P\&G might have entered the bleach market at some point in the future, and that as a very successful consumer product producer its threat of entry may (somehow) have limited Clorox's market power. ${ }^{9}$ Second, the merger would have allowed P\&G to more effectively promote Clorox (through reductions in the cost of advertising), and this decline in promotion costs would have harmed competition by causing entry to be less likely. ${ }^{10}$ In essence, the Court ruled that merger efficiencies are illegal if they cause the merged firm's costs to be so low that rivals cannot profitably enter.

\section{Bork's View of Effective Merger Policy}

As he describes in the forward to The Antitrust Paradox, Robert Bork completed his first draft in 1969, shortly after the Supreme Courts Clorox and Von's Grocery decisions, and the book reads as a vigorous response to these and other similarly aggressive antitrust actions. In The Antitrust Paradox, Bork frames his analysis of mergers using Williamson’s (1968) classic paper outlining the potential welfare tradeoff resulting from horizontal mergers. Using a very simple model, Williamson described how mergers could simultaneously result in cost reductions and reductions in output. Williamson suggested that in determining which mergers to challenge,

\footnotetext{
${ }^{9}$ The court cites the FTC's statement that "prior to the merger the Commission found, Proctor was the most likely prospective entrant into the industry, and absent the merger would have remained on the periphery, restraining Clorox from exercising its market power." FTC vs. Proctor and Gamble.

${ }^{10}$ The court wrote, "The acquisition may also have the tendency of raising barriers to new entry. The major competitive weapon in the successful marketing of bleach is advertising. Clorox was limited in this area by its relatively small budget and its inability to obtain substantial discounts....Proctor would be able to use its volume discounts to advantage in advertising Clorox. Thus, a new entrant would be much more reluctant to face the giant Proctor than it would have been to face the smaller Clorox.” FTC vs. Proctor and Gamble.
} 
regulators should explicitly tradeoff the positive productive effects of mergers against the deadweight loss resulting from mergers that increase market power. As we discuss below in more detail, Bork did not think that Williamson's suggested tradeoff could be effectively used in practice. However, Bork felt that Williamson's model provided a very important insight for merger policy: mergers cannot be harmful unless they result in a reduction in output. If the government cannot produce a credible theory of how a merger harms competition, then it should allow the merger to proceed. ${ }^{11}$ Therefore, the primary focus of merger analysis should focus on determining if there is a reasonable probability that the specific merger before the agencies will harm competition. While Bork’s policy recommendation seems uncontroversial today, at the time it represented a significant break from a consensus view as seen in the 1968 Merger Guidelines and Von's Grocery; that is, showing that a merger either increased concentration or was taking place in a market that was experiencing consolidation was sufficient to show that the a merger was anticompetitive.

While Bork conceded that some mergers could create market power and reduce consumer welfare, he felt that those mergers were limited to those that created either a monopoly or a dominant firm. He was quite skeptical that mergers would create or enhance competitive problems resulting from oligopoly. For example, Bork wrote that "oligopolistic behavior, to the extent that it exists at all (and I am not persuaded that such behavior exists outside of economics textbooks) rarely results in any significant ability to restrict output.”12 The difficulty facing regulators was in determining whether to challenge a merger when there was evidence suggesting that a merger would both increase market power and result in important efficiencies.

\footnotetext{
11 "If a practice does not raise a question of output restriction, however, we must assume that its purpose and therefore its effect are either the creation of efficiency or some neutral goal. In that case the practice should be held lawful.” The Antitrust Paradox, page 122.

${ }^{12}$ The Antitrust Paradox, page 221.
} 
Bork did not think that regulators would be capable of the balancing exercise suggested by Williamson because precisely measuring either deadweight loss or merger efficiencies was extremely difficult in the best of circumstances, and often impossible. A formal balancing exercise would require economists to know or estimate "the demand curve over all possibly relevant ranges of output and the marginal cost curve over those same ranges." ${ }^{, 13}$ The subsequent "trial would then proceed to the measurement of efficiency and restriction of output under an imaginary set of circumstances: what would the net contribution to consumer welfare be if the two firms were merged into one?”14 Bork also expressed the (in hindsight, prescient) fear that if courts and regulators attempted to engage in this balancing act, they would focus on only those efficiencies that can be measured even though those efficiencies may not be the most important. ${ }^{15}$ Bork argued that the most important merger efficiencies, such as the transfer of assets to more capable management, would not be considered valid under a balancing test. ${ }^{16}$

Bork did not provide a precise description of how to balance the efficiency benefits and competitive harms of proposed mergers. He argued that if the regulator believed the chances that the merger was competitively harmful or beneficial were roughly the same, then the government should allow the merger to proceed. ${ }^{17}$ For the remaining cases, Bork suggested that

\footnotetext{
${ }^{13}$ The Antitrust Paradox, page 125.

${ }^{14}$ The Antitrust Paradox, page 125.

15 "Economists, like other people, will measure what is susceptible to measurement and will tend to forget what is not, though what is forgotten may be far more important than what is measured.” The Antitrust Paradox, page 127. 16 "The most important thing about the Ford Motor Co. in its early years was the genius of Henry Ford, just as the most important efficiency of General Motors Corp. in later years was the organizational genius of Alfred Sloan. The acquisition of one of those companies of a rival would have extended to a new group of resources a management that was enormously superior, even if there were no cost cuts to be expected but only the doing of better things at higher costs.” The Antitrust Paradox, page 129.

${ }^{17}$ Bork provides two economic justifications for his conclusion. First, he argues that because blocking mergers is costly, it does not make sense to invest resources where the expected value of harm is zero. Second, if a merger proves to be anticompetitive, market forces will eventually right the situation. The Antitrust Paradox, page 133. The counter argument to Bork's recommendation is that by successfully challenging these marginal mergers the government can deter firms from filing mergers that might lead to small price increases. Over time, this deterrence effect could lower the agency's enforcement costs. Clougherty and Seldeslachts (2013) provide evidence on deterrence effects in the U.S.
} 
appropriately constructed market share thresholds (much more lenient than those in the 1968 Guidelines) would minimize the harm from anticompetitive mergers. He stated that:

"My guess is ..., that mergers of up to 60 or 70 percent of the market should be permitted....Partly as a tactical concession to the current oligopoly phobia and partly in recognition of Section 7's intended function of tightening the Sherman Act rule, I am willing to weaken that conclusion. Competition in the sense of consumer welfare would be adequately protected and the mandate of Section 7's satisfactorily served if the statute were interpreted as making presumptively lawful all horizontal mergers up to market shares that would allow for other mergers of similar size in the industry and still leave three significant companies. ${ }^{18}$

Thus, if Bork was correct, a merger policy that banned "3 to 2" mergers but allowed "4 to 3" mergers would be sufficient to maintain consumer welfare.

Bork also devoted significant discussion to the federal government's challenges of conglomerate mergers such as $P \& G / C l o r o x$. Bork felt that there was "no threat to competition in any conglomerate merger," because conglomerate mergers do not change the incentives of the merged firm such that it would choose to reduce output. ${ }^{19}$ Most of the concern about conglomerate mergers in the 1950s and 1960s was that the acquisition of a (typically) smaller firm in an unrelated market by a very large corporation, would harm rivals in the unrelated markets. For example, in the Clorox case, $P \& G$ with its deep financial resources would provide Clorox with access to capital that could be invested in advertising and marketing to the detriment of Clorox's rivals. Under conglomerate theories, merger efficiencies (access to capital at lower prices or even superior management) were often viewed as harmful to competition because they

\footnotetext{
${ }^{18}$ The Antitrust Paradox, pages 221-222.

${ }^{19}$ The Antitrust Paradox, page 246.
} 
harmed rivals. Bork strongly argued that this policy was only sensible "if 'competition' is defined as a comfortable life for competitors. ${ }^{20}$ The one conglomerate theory that Bork felt had some legitimacy was a threat to potential entry. However, he argued strongly that this theory was really a horizontal theory: the merger caused the acquiring firm to not enter the market and expand output. Bork felt that in very limited circumstances the government would be justified in blocking mergers under a theory of potential competition. ${ }^{21}$

Bork's views of conglomerate mergers have become the consensus view in the U.S. While U.S. antitrust agencies periodically challenge mergers under potential competition theories, ${ }^{22}$ to our knowledge, there have not been any challenges of true conglomerate mergers in the U.S. in the modern era. ${ }^{23}$

\section{Changes in Antitrust Enforcement Post-Antitrust Paradox}

Merger review has become both more systematized and fact intensive in the U.S. since the publication of The Antitrust Paradox. Both the federal antitrust agencies and the federal courts increasingly demand direct evidence demonstrating why a specific proposed acquisition will be anticompetitive, see, e.g., FTC v. Staples or U.S. v. Oracle. Except in extreme circumstance (mergers to monopoly or duopoly in undisputed markets), courts are unlikely to block mergers today solely because of an increase in market concentration. While there are undoubtedly many

\footnotetext{
${ }^{20}$ The Antitrust Paradox, page 254.

21 "If there are three significant firms, an outside firm should be permitted to acquire any of them. If there is one large firm and a scattering of small firms, the outside firm should be allowed to acquire any of the smaller firms, or it should be allowed to acquire the largest firm unless it has, say, over $70 \%$ of the market.” The Antitrust Paradox, page 260.

${ }^{22}$ For example, in challenging a merger of innovator firms in the pharmaceutical industry where both firms were attempting to develop a product to serve the same market, the government often requires the merged firms to divest one of the firm's research programs before approving the merger.

${ }^{23}$ Conglomerate mergers do appear to be challenged outside the U.S., most notably in the European Union's decision to block the GE/Honeywell merger in 2001. See Kolasky (2001) for a discussion available at: http://www.justice.gov/atr/public/speeches/9536.htm (last checked October 17, 2013).
} 
reasons for these changes in enforcement, we highlight three key changes that have, collectively, dramatically changed the composition of challenged U.S. mergers.

First, the market share thresholds that generate competitive concern by antitrust enforcers have increased substantially since Von’s Grocery. The 1968 Merger Guidelines stated that the DOJ would "ordinarily challenge” a horizontal merger of two firms each with a $5 \%$ market share in a 'less highly concentrated market." ${ }^{24}$ In contrast, the 2010 Horizontal Merger Guidelines states that only mergers taking place in highly concentrated markets (with a post-merger Hirschman-Herfindahl Index-HHI-- above 2500) are "presumed to be likely to enhance market power.”25 The change in the concentration thresholds at which the federal antitrust agencies typically challenge mergers stated in the Guidelines can also be seen in the agencies’ enforcement behavior. According to a recent report by the FTC, of all markets in which mergers were challenged between fiscal years 1996 and 2011, 85\% were in markets with a post-merger HHI of more than $2400 .^{26}$ Thus while not as permissive as Bork suggested, U.S. antitrust agencies now allow mergers in much more concentrated markets than at the time Bork wrote.

Second, and in sharp contrast to the Court's opinion in the Clorox case, antitrust enforcers now understand that merger efficiencies can offset a merged firm’s incentive to increase price. Mergers are now evaluated under the consumer welfare standard: mergers that are expected to increase consumer prices (lower consumer welfare) are illegal. ${ }^{27}$ The 1984, 1992, 1997, and 2010 Merger Guidelines each devote a separate section to the importance of merger efficiencies, and describe the circumstances under which merger efficiencies will be considered as part of a

\footnotetext{
241968 Merger Guidelines, Horizontal Mergers, Section 6.

252010 Horizontal Merger Guidelines, Section 5.3.

${ }^{26}$ FTC (2013), table 3.1.

${ }^{27}$ This is a very different policy than the total welfare standard endorsed by many economists, e.g., Williamson (1968). Under a total welfare standard, mergers that harm consumers by raising prices are permissible so long as the gains in producer surplus are sufficient to offset the deadweight lost caused by the price increase.
} 
merger investigation. Moreover, efficiency considerations can play an important role in the antitrust agencies’ enforcement decisions. According to the DOJ, the joint venture of Miller and Coors, which combined their U.S. operations and dramatically increased market concentration, was allowed, in part, because:

“The Division verified that the joint venture is likely to produce substantial and credible savings that will significantly reduce the companies’ costs of producing and distributing beer... The large amount of these savings and other evidence obtained by the Division supported the parties’ contention that the venture should make a lower-cost, and therefore more effective, beer competitor.,28

Thus, unlike in the days of Clorox, it is no longer the case that merger efficiencies can cause a horizontal merger to be ruled illegal. Current enforcement behavior reflects Bork's view that the overwhelming majority of mergers are either competitively neutral and/or efficiency enhancing: over the last decade (2003-2012), 96.8\% of the mergers filed with the antitrust agencies were allowed to proceed without undergoing a full merger investigation. ${ }^{29}$

Finally, the major institutional change in merger enforcement—-the government's legal right to review and challenge proposed mergers prospectively as granted by the Hart-Scott Rodino Act (HSR Act)—has profoundly changed the process by which federal agencies review mergers. Prior to the passage of the HSR Act in 1976, most companies were under no obligation to notify the government of their intent to merge or to delay a merger's consummation to allow the government time to investigate the proposed transaction. ${ }^{30}$ As a result, the government's merger review frequently began after a merger was consummated, and in the event the merger was

\footnotetext{
${ }^{28}$ See DOJ closing statement available at: http://www.justice.gov/atr/public/press releases/2008/233845.pdf, last visited October 21, 2013.

${ }^{29}$ That is, $96.8 \%$ of mergers were allowed to proceed without receiving a second request from the antitrust agencies. Authors' calculations using data in Appendix A of the Hart- Scott-Rodino Annual Report (2012).

${ }^{30}$ See Baer (1997) for a discussion of pre-HSR merger enforcement.
} 
subsequently challenged, years would pass before the litigation was resolved. The social value of such litigation was dubious. Consumers experienced lost competition for up to a decade. Moreover, even following a successful trial, it was often difficult for the government and the combined firms to reconstruct a new entity to replicate the competition removed by the merger (Elzinga (1969)).

The passage of the HSR Act eliminated these problems and greatly simplified merger review in the U.S. The HSR Act established the government's right to review mergers before they were consummated. Under the law, all firms participating in a merger of sufficient size must file an intent to merge with both the DOJ and the FTC which includes key documents describing the proposed transaction for all mergers of a sufficiently large size. The government then has 30 days to determine if it requires more information to determine if the merger is likely to harm competition. In that event, the government can issue a detailed request for documents from the merging parties (“a second request”). The firms cannot consummate their merger until the government has had 30 days to review all second request material. After its review, the government can sue to block the merger in Federal District Court.

The effect of the HSR Act on merger analysis has been enormous. Because merger review has been routinized, the federal antitrust agencies have been able to systematize merger review in a way that was not previously possible. Over time, the agencies have developed standardized methodologies for conducting merger review that are described in a set of formal guidelines. The post-HSR Horizontal Merger Guidelines and their revisions (1982, 1984, 1992, 1997, 2010) describe the key questions that must be addressed by the government before challenging a horizontal merger: entry, efficiencies, market definition, and the articulation of the government's theory as to how the merger will harm consumers. As the agencies have modified their 
procedures over time, the Guidelines are updated to provide transparency to the antitrust community. The current (2010) version of the Horizontal Merger Guidelines, for example, provides a detailed description of the types of evidence the agencies consider in evaluating the competitive effects of a proposed merger.

In evaluating Bork's proposals for merger review, it is important to note how much the process of merger review has changed, and how much more is required of the government to successfully challenge a merger. In particular, the set of mergers challenged by the federal agencies has changed substantially in the years following the passage of the HSR Act. While the Vons Grocery decision has not been explicitly overturned by the Supreme Court, we would be very surprised to see either U.S. antitrust agency challenge a merger in such an unconcentrated market today. Bork's prediction that the typically challenged merger in an oligopolistic industry would not have harmed consumers may have been correct given the composition of mergers taking place in the 1960s and 1970s. As we discuss below, given current enforcement thresholds, the empirical evidence shows that mergers can increase market power in oligopolistic markets.

\section{Can Horizontal Mergers in Oligopolistic Markets be Anticompetitive?}

Whether U.S. merger policy has been effectively employed to maintain consumer welfare is an open and controversial policy question. ${ }^{31}$ To evaluate Bork’s claims as to the likely competitive effects of mergers, and, more generally, to provide evidence on the overall effectiveness of horizontal merger policy, we have conducted a survey of the literature that

\footnotetext{
${ }^{31}$ In their analysis of U.S. competition policy, Crandall and Winston (2003) concluded "that efforts by antitrust authorities to block particular mergers or affect a merger's outcome by allowing it only if certain conditions are met under a consent decree have not been found to increase consumer welfare in any systematic way, and in some instances the intervention may even have reduced consumer welfare.” Crandall and Winston (2003), page 20.
} 
estimates the price effects of consummated horizontal mergers. ${ }^{32}$ In conducting this survey, we have excluded papers that have focused on the vertical aspects of mergers ${ }^{33}$ and transactions involving horizontal agreements that fall short of complete integration. ${ }^{34}$ Our survey identified 49 distinct studies examining mergers taking place in 21 industries published over the last 30 years.

The majority of papers in this paper have a similar study design. ${ }^{35}$ Under U.S. law, antitrust agencies are supposed to block mergers that reduce consumer welfare. If the agencies are operating effectively, on average, the marginal merger (the merger the agency is on the margin of challenging) should not result in a quality adjusted price increase. Researchers test the agencies' effectiveness by first identifying consummated mergers that were likely to be on the enforcement margin, and then estimating how prices change following those mergers. If prices are found to increase systematically following marginal mergers, then enforcement has not been aggressive enough. Similarly, if prices, on average, fall following marginal mergers, then it follows that enforcement has been too aggressive. That is, the marginal merger allowed was one where merger efficiencies more than offset the combined firm's merger induced incentive to increase price.

Most studies in this literature use a case-study approach. The typical study examines one or a handful of mergers taking place in the same (or similar) industries at roughly the same time

\footnotetext{
${ }^{32}$ Given both the recent growth in this literature and the variety of industries studied, it is quite likely that we have inadvertently missed some studies and apologize for any omission. See Pautler (2003), Weinberg (2008), Hunter et al. (2008), and Kwoka (2013) for other surveys of this literature.

${ }^{33}$ For example, we do not include Hastings and Gilbert (2005) and Hastings (2004) which focus on the vertical aspects of transactions in the petroleum industry.

${ }^{34}$ Kwoka (2013) includes code-share agreements between airlines in his recent review of horizontal merger studies, and concludes that most lower consumer prices. While code-share agreements do combine some aspects of competing airlines operations, these actions are quite different than mergers. Mergers likely offer significantly more opportunities for both anticompetitive effects (reductions in routes or coordination of pricing) and efficiencies (consolidation of operations).

${ }^{35}$ See Carlton (2009) and Ashefelter, Hosken, and Weinberg (2009) for a detailed discussion of the methodological issues involved in measuring the effectiveness of competition policy.
} 
and identify merger price effects relative to some control product. A smaller number of studies attempt to measure the average price effect of many mergers using a common methodology. Obviously, in this type of study it is impossible to provide much detail about the specific transactions being analyzed. Even in these broader studies, however, the authors frequently provide some evidence on the competitive significance of the mergers studied. For example, Prager and Hannan (1998) and Focarelli and Panetta (2003) both include estimates of merger price effects for those markets experiencing large changes in market concentration.

Unfortunately, the mergers studied do not constitute a representative sample of all potentially anticompetitive mergers. The set of mergers which can be studied is severely limited by data availability. Most merger studies examine mergers in one of four industries which have experienced a large number of mergers and where data is available: airlines, banking, hospitals, and petroleum. The remainder of the literature is quite diverse reflecting circumstances where a researcher can identify both a potentially anticompetitive merger and data sufficient to estimate the price effects of the merger.

For each study we have included in the survey, we identify the specific mergers studied (when enumerated by the researcher), provide a terse description of the study, describe what (if any) evidence the author provides that the merger(s) was on the enforcement margin, and state the study’s estimated merger price effect. To facilitate comparison across studies, we have grouped the studies together for the airline (Table 1), banking (Table 2), hospital (Table 3), and petroleum (Table 4) studies. The summary of the studies in “Other Industries” is shown in Table 5.

As can be seen by a quick review of Tables 1-5, the estimated price effects of mergers varies dramatically across industries, and even across studies estimating the price effects of a 
given merger. Four studies have estimated the price effect of the 1986 merger of Northwest

Airlines and Republic Airlines, for example, and found price effects of: 9.5\%, 5.6\%, -1.8\%, and

7.2\% (Table 1). Because of important differences in methodology, industry, data, and time

period across studies, we do not calculate aggregate estimates of the "typical” price effect of a

merger. Instead, we present the findings of each study separately and then draw general

conclusions about the competitive impact of horizontal mergers.

The empirical evidence that mergers can cause economically significant increases in

price is overwhelming. Of the 49 studies surveyed, 36 find evidence of merger induced price

increases. ${ }^{36,37}$ All of the airline merger studies find evidence of price increases, although the

magnitude of the price increases appears to be more modest following recent mergers (2-6\%)

when compared to the mergers that took place in the 1980s. Similarly, most of the banking (6 of

7), hospital (5 of 7), and “other industry” (13 of 18) studies find evidence that mergers have

resulted in price increases.

It is unclear if mergers in the petroleum industry have increased consumer prices. Of the nine studies that have estimated the price effects of horizontal mergers, four (three examining multiple mergers) found that mergers increased prices, while the remaining studies found either no meaningful change in pricing associated with mergers or ambiguous results. Institutional characteristics of petroleum markets, in particular the sensitivity of gasoline pricing to supply shocks, make the results of these studies especially sensitive to modeling assumptions. While

\footnotetext{
${ }^{36}$ We define a merger as increasing price if the merger caused as least some product prices to rise, and no product prices to fall. For example, Ashenfelter, Hosken, and Weinberg (2013a) find that the acquisition of Maytag by Whirlpool caused the prices of some dryers and dishwashers to increase while not lowering the price of other appliances. From this evidence we conclude the Maytag/Whirlpool merger caused prices to increase. Similarly, if a merger lowers some prices and leaving other prices unchanged, we conclude that merger lowered prices. A merger that raises some prices while lowering others, e.g., Thompson (2011), has ambiguous price effects.

${ }^{37}$ Because many of the studies examined multiple mergers, it is possible for a study to find evidence of both merger price increases and merger price decreases. For example, Hosken, Olson, Smith (2012) find that of the 14 supermarket mergers they examine, five lead to price increases, five lead to price decreases, and four resulted in no meaningful change in consumer prices.
} 
the literature is not be able to tell us if mergers at observed levels of market concentration have increased gasoline prices, it does provide information to bound the potential price effects of mergers. Of those studies finding price increases, most report very small price effects, on the order of 1-2 cents per gallon (see Table 4). Only one study, GAO (2004), reports larger price effects, varying from 1-7 cents per gallon. Thus, relative to the typical price variation associated with gasoline prices, even the maximum estimated price effects associated with petroleum mergers are quite modest.

Overall, the results from the merger retrospective literature show that mergers in oligopolistic markets can result in economically meaningful price increases. While some of the airline merger studies discussed above examined mergers that reduced the number of airlines serving city pairs to one or two firms, many studies in this literature find that prices have increased in markets with at least three major firms operating post-merger. ${ }^{38}$ The Ashenfelter, Hosken, and Weinberg (2013a) study, for example, estimates the price effects of the 2008 acquisition of the major appliance manufacturer, Maytag, by Whirlpool. As predicted by a conventional unilateral effects theory, the authors find that for those appliance categories experiencing a price increase, the prices of products sold by the combined Maytag/Whirlpool increased more than those sold by rivals. Contrary to Bork's prediction, three major firms in an industry are not sufficient to maintain competition.

While the literature shows that mergers on the enforcement margin increase prices more often than not, it is not the case that every marginal merger increases consumer prices. Of the 49 studies we surveyed, 13 find evidence of price reductions following a merger, and 13 find evidence of no meaningful change in price following a merger. Ashenfelter and Hosken (2010),

\footnotetext{
${ }^{38}$ See, for example, McCabe (2002), Ashenfelter and Hosken (2010), Tenn (2011), Dafny, Duggan, and Ramanarayanan (2012), and Hosken, Olson, and Smith (2012).
} 
for example, estimate the price effects of mergers in five consumer goods industries: liquor, feminine hygiene, passenger car motor oil, breakfast cereals, and pancake syrups. While they found that prices rose in four of five markets, the market experiencing the largest increase in market concentration (pancake syrups) did not experience a post-merger price increase. Similarly, Haas-Wilson and Garmon (2011) estimate the price effects of two hospital mergers taking place in the Chicago, Illinois suburbs in 2000. The first merger involved two hospitals located in the same city that were relatively distant from other hospitals. This merger did not increase prices. The second merger combined hospitals both more distant from one another and facing competition from rivals located closer than those in the first merger, and resulted in a price increase. We highlight these two examples to show the importance of institutional factors in merger analysis. The ability to generalize findings from one market to another is limited. Markets facing what may appear to be similar levels of pre-merger competition (e.g., levels of market concentration) can experience very different post-merger outcomes. Thus, while market concentration can provide a useful screen in determining which mergers to investigate, casespecific evidence (industry documents, explicit estimates of consumer substitution patterns) are critically important to decision makers in making correct enforcement decisions.

The merger retrospective literature focuses almost exclusively on measuring the short-run effect of mergers on prices. This limitation is largely driven by data availability. Obtaining access to the detailed price data required to credibly estimate the price effects of mergers is difficult, and most often only relatively short price series are available. However, even in those cases where relatively long price series are readily available, e.g., banking or petroleum markets, it is often difficult to build a credible forecast of the counterfactual using the standard program evaluation techniques frequently used in this literature. That is, while it is often possible to find 
candidate "control" products whose prices track the prices of the merging products well in the years immediately prior to the merger, it often strains credibility to claim that these same products' prices continue to provide a reasonable forecast of the counterfactual 5,10 , or 15 years following a merger. Over such long time periods, idiosyncratic shocks to costs or demand are likely to cause the merger and control products' prices to diverge.

This limitation of the literature is potentially important. As we discuss in more detail in the next section, the efficiencies which act to offset the anticompetitive effects of mergers take time to be realized. Four of the five studies we are aware of that attempt to estimate intermediate or long-run effects of mergers find that the short run price increases associated with mergers dissipate or are reversed in the long run. ${ }^{39}$

\section{Are Merger Efficiencies Important?}

While a large literature addresses the efficiency of mergers, ${ }^{40}$ we limit our attention here to a very small empirical literature that examines those efficiencies relevant to antitrust analysis: efficiencies that can potentially offset the combined firm's incentive to increase price as a result of increased market power. The best known published paper finding evidence of this type of merger efficiency is the Focarelli and Panetta (2003) study of Italian banking mergers. Focarelli and Panetta find that while deposit rates paid to consumers fall in the years directly following a merger, in later years deposit rates increase above pre-merger levels. Focarelli and Panetta argue that initially the merging firms were able to lower deposit rates because of increased market

\footnotetext{
${ }^{39}$ See, Focarelli and Panetta (2003), Winston, Maheshri, and Dennis (2011), Ashenfelter, Hosken, and Weinberg (2013b), and Huschelrath and Muller (2013).

${ }^{40}$ This literature is primarily focused on measuring whether mergers and acquisitions increase shareholder wealth (most often using stock market event studies) or examining how mergers affect the efficiency with which a firm is operated. This latter literature is largely focused on the regulated industries (most often the financial industry) where measures of firm inputs are available from regulatory filings. See DeYoung, Evanoff, and Molyneux (2009) for a review of merger efficiency studies in the financial services industry. Other industries studied include electricity generation (Kwoka and Pollitt's (2010)), railroads (Breen (2004) and Bitzan and Wilson (2007)), and hospitals (Harrison (2011)).
} 
power, and over time, as the firms gained efficiencies from consolidation they began to pass through reductions in costs in the form of increased deposit rates. Focarelli and Panetta do not identify the mechanism by which the combined firm lowers its costs. Instead, they infer efficiencies through increases in the deposit rate offered to consumers over time. These results are often cited as evidence that the market power effects of mergers are often felt shortly after a merger, while efficiency effects may take much more time to materialize.

The most direct evidence of merger efficiencies we are aware of comes from Ashenfelter, Hosken, and Weinberg's (2013b) study of the 2008 joint venture between Coors and Miller that combined their U.S. brewing operations. The U.S. brewing industry has long been subject to aggressive antitrust enforcement. ${ }^{41}$ Given this extensive history, it was perhaps surprising that the DOJ allowed the merger to proceed without modification despite a high level of market concentration. ${ }^{42,43}$ As noted previously, the DOJ stated that it allowed this merger, in part, because the firms showed the merger would likely result in credible efficiencies that would lower the cost of producing and distribution beer. One of the leading costs of beer is distribution: shipping beer from the brewery to the retail outlet. Prior to the merger Coors operated two U.S. breweries, one in Colorado and one in Virginia, while Miller operated six breweries that were more evenly spread throughout the U.S. Because Miller’s breweries were not capacity constrained, the combined firm may have been able to lower its shipping costs by moving some Coors production to Miller plants closer to final consumers.

\footnotetext{
${ }^{41}$ See the Tremblay and Tremblay (2005) study of the U.S. brewing industry for an extensive discussion of U.S. antitrust enforcement in brewing.

${ }^{42}$ In concluding their discussion of mergers in the U.S. brewing industry, Tremblay and Tremblay (2005) state, "Today the only potential mergers with anti-trust implications would involve Anheuser-Busch, Miller, Coors, and Pabst. A merger between any two of these would undoubtedly be challenged unless one firm was clearly failing." page 247.

${ }_{43}$ Ashenfelter, Hosken, and Weinberg report that in their sample of 48 markets, the average pre-merger HHI was 2170 with an increase of roughly 480 caused by the merger.
} 
Ashenfelter, Hosken, and Weinberg separately identify market power effects and efficiency effects of the merger by exploiting geographic variation in how the merger was expected to increase concentration and reduce costs. They find that increased market concentration increased beer prices, and that reductions in shipping distances lowered prices. On net, in the average market, the merger efficiencies appeared to almost exactly offset the price increase resulting from increased concentration. In addition, like Focarelli and Panetta, the authors find compelling evidence that market power effects caused by the merger occurred shortly after the merger was consummated, while merger efficiencies were realized later (roughly 18 months following the merger) as the combined firm re-optimized its production.

\section{Conclusion}

In The Antitrust Paradox, Robert Bork called for a revolutionary change in merger policy. He directly challenged the orthodoxy that increasing levels of market concentration generally harmed consumers. He emphasized that many factors associated with mergers, such as attaining economies of scale in production or advertising, harmed competitors and not competition. Bork's advocacy clearly played an important role in changing the consensus view of the purpose of competition policy in the U.S.: to protect consumers rather than competitors.

Bork did not think that the typical horizontal merger would harm consumers. He argued that most horizontal mergers allowed successful firms to expand by better utilizing the assets of a rival. Bork viewed the major potential harm of horizontal mergers as the creation of a dominant firm or monopoly, and was quite dubious that mergers could create harm in oligopolistic markets. In speculating what market share thresholds should guide horizontal merger policy, 
Bork, in essence, argued that mergers that resulted in at least three significant firms would not be likely to harm competition.

Although Bork was surely right that most horizontal mergers have no meaningful negative impact on competition, the empirical record rejects Bork's views on mergers in oligopolistic industries. Ex-post evaluations of consummated mergers have found that prices can increase following mergers leaving only three or four major market participants. This implies that mergers within oligopolistic industries can lead to consequential increases in market power, even if they do not result in monopolies or dominant firms.

Our conclusions, however, should not be read as an indictment of Bork's general views on merger policy. Given the aggressiveness of horizontal merger policy when Bork was writing The Antitrust Paradox, it is quite probable that the price effect of the marginal merger was then negative. Because so many of the merger policy recommendations Bork advocated have gone into effect, the composition of challenged and nearly challenged mergers has changed dramatically since the publication of The Antitrust Paradox. Moreover, economists and attorneys no longer advocate challenging mergers because of some vague sense that an oligopoly problem will be made worse. Instead, direct evidence is brought to bear to show whether the products produced by the merging firms are (or are not) close substitutes. While Bork's specific policy recommendations may have been too permissive, the general changes he advocated for horizontal merger policy have likely improved consumer welfare. 


\section{References}

Aguzzoni, Luca, Elena Argentsi, Lorenzo Ciari, Tomaso Duso, and Massimo Tognoni. 2013. “Ex Post Merger Evaluation in the UK Retail Market for Books.” mimeo

Allen, Jason, Rob Clark, and Jean Francois Houde. 2013. “The Effects of Mergers in

Search Markets: Evidence from the Canadian Mortgage Industry,” NBER Working Paper 19126

Allain, Marie-Laure, Claire Chambolle, Stephane Turolla, and Sofia Villas-Boas. 2013.

“The Impact of Retail Merges on Food Prices: Evidence from France,” ALISS Working Paper 2013-1

Ashenfelter, Orley, and Daniel Hosken. 2010. "The Effect of Mergers on Consumer Prices: Evidence from Five Mergers on the Enforcement Margin." Journal of Law And Economics 53, no. 3: 417-466.

Ashenfelter, Orley, Daniel Hosken, and Matthew Weinberg. 2009. "Generating Evidence to Guide Merger Enforcement." Competition Policy International 5, no. 1: 67-85.

----. 2013a. "The Price Effects of a Large Merger of Manufacturers: A Case Study of Maytag-Whirlpool." American Economic Journal: Economic Policy 5, no. 1: 239-261.

----. 2013b. "Efficiencies Brewed: Pricing and Consolidation in the U.S. Beer Industry." NBER Working Paper 19353

Baer, William J. 1997. "Reflections on twenty years of merger enforcement under the Hart-Scott-Rodino Act." Antitrust Law Journal 65, no. 3: 825-864.

Baker, Jonathan and Carl Shapiro. 2009. “Reinvigorating Horizontal Merger Enforcement” in How the Chicago School Overshot the Mark, ed. Robert Pitofsky. Oxford University Press: New York. 
Barton, David M., and Roger Sherman. 1984. "The Price and Profit Effects of Horizontal Merger: A Case Study." Journal Of Industrial Economics 33, no. 2: 165-177.

Bitzan, John D., and Wesley W. Wilson. 2007. "Industry Costs and Consolidation:

Efficiency Gains and Mergers in the U.S. Railroad Industry." Review of Industrial Organization 30, no. 2: 81-105.

Bjornerstedt, Jonas, and Frank Verboven. 2013. "Does Merger Simulation Work? A 'Natural Experiment' in the Swedish Analgesics Market Market." mimeo

Borenstein, Severin. 1990. "Airline Mergers, Airport Dominance, and Market Power." American Economic Review 80, no. 2: 400-404.

Bork, Robert. 1979. The Antitrust Paradox . Basic Books: New York.

Breen, Denis A. 2004. "The Union Pacific/Southern Pacific Rail Merger: A Retrospective on Merger Benefits." Review of Network Economics 3, no. 3: 283-322.

Calomiris, Charles W., and Thanavut Pornrojnangkool. 2005. "Monopoly-Creating Bank Consolidation? The Merger of Fleet and BankBoston." NBER Working Paper 11351

Carlton, Dennis W. 2009. "Why We Need to Measure the Effect of Merger Policy and How to Do It." Competition Policy International 5, no. 1: 87-100.

Chandra, Ambarish, and Allan Collard-Wexler. 2009. "Mergers in Two-Sided Markets: An Application to the Canadian Newspaper Industry." Journal Of Economics And Management Strategy 18, no. 4: 1045-1070.

Chone, Philippe, and Laurent Linnemer. 2012. "A Treatment Effect Method for Merger Analysis with an Application to Parking Prices in Paris." Journal Of Industrial Economics 60, no. 4: 631-656. 
Chouinard, Hayley H., and Jeffrey M. Perloff. 2007. "Gasoline Price Differences: Taxes, Pollution Regulations, Mergers, Market Power, and Market Conditions." B.E. Journal of Economic Analysis And Policy: Contributions To Economic Analysis And Policy 7, no. 1: 1-26. Clougherty, Joseph A., and Jo Seldeslachts. 2013. "The Deterrence Effects of US Merger Policy Instruments." Journal Of Law, Economics, And Organization 29, no. 5: 1114-1144 Connor, Robert A., Roger D. Feldman, and Bryan E. Dowd. 1998. "The Effects of Market Concentration Horizontal Mergers on Hospital Costs and Prices." International Journal Of The Economics Of Business 5, no. 2: 159-180.

Crandall, Robert W., and Clifford Winston. 2003. "Does Antitrust Policy Improve Consumer Welfare? Assessing the Evidence." Journal Of Economic Perspectives 17, no. 4: 3-26. Dafny, Leemore. 2009. "Estimation and Identification of Merger Effects: An Application to Hospital Mergers." Journal of Law And Economics 52, no. 3: 523-550.

Dafny, Leemore, Mark Duggan, and Subramaniam Ramanarayanan. 2012. "Paying a Premium on Your Premium? Consolidation in the US Health Insurance Industry." American Economic Review 102, no. 2: 1161-1185.

Deneckere, Raymond, and Carl Davidson. 1985. "Incentives to Form Coalitions with Bertrand Competition." RAND Journal of Economics 16, no. 4: 473-486

DeYoung, Robert, Douglas D. Evanoff, and Philip Molyneux. 2009. "Mergers and Acquisitions of Financial Institutions: A Review of the Post-2000 Literature." Journal Of Financial Services Research 36, no. 2-3: 87-110.

Ellickson, Paul B. 2007. "Does Sutton Apply to Supermarkets?." RAND Journal of Economics 38, no. 1: 43-59. 
Elzinga, Kenneth G. 1969. "The Antimerger Law: Pyrrhic Victories?." Journal of Law And Economics 12, no. 1: 43-78

FTC v. The Proctor and Gamble Company, 386 U.S. 568 (1967).

FTC v. Staples, Inc. 970 F.Supp. 1066 (DDC 1997)

Federal Trade Commission 2013. Horizontal Merger Investigation Data Fiscal Years 1996-2011. Washington, DC: FTC

Focarelli, Dario, and Fabio Panetta. 2003. "Are Mergers Beneficial to Consumers? Evidence from the Market for Bank Deposits." American Economic Review 93, no. 4: 1152-1172 Garmaise, Mark J., and Tobias J. Moskowitz. 2006. "Bank Mergers and Crime: The Real and Social Effects of Credit Market Competition." Journal Of Finance 61, no. 2: 495-538.

Guardado, Jose, David Emmons, and Carol Kane. 2013. “The Price Effects of a Large Merger of Health Insurers: A Case Study of UnitedHealth-Sierra.” Health Management, Policy and Innovation 1, no. 3: 16-35.

Haas-Wilson, Deborah, and Christopher Garmon. 2011. "Hospital Mergers and Competitive Effects: Two Retrospective Analyses." International Journal of The Economics of Business 18, no. 1: 17-32.

Harrison, Teresa D. 2011. "Do Mergers Really Reduce Costs? Evidence from Hospitals." Economic Inquiry 49, no. 4: 1054-1069.

Hastings, Justine S. 2004. "Vertical Relationships and Competition in Retail Gasoline Markets: Empirical Evidence from Contract Changes in Southern California." American Economic Review 94, no. 1: 317-328.

Hastings, Justine S., and Richard J. Gilbert. 2005. "Market Power, Vertical Integration and the Wholesale Price of Gasoline." Journal Of Industrial Economics 53, no. 4: 469-492. 
Hosken, Daniel, Luke Olson, and Loren Smith. 2012. "Do Retail Mergers Affect Competition: Evidence from Grocery Retailing," FTC Bureau of Economics Working Paper \#313

Hosken, Daniel, Louis Silvia, and Christopher Taylor. 2011. "Does Concentration Matter? Measurement of Petroleum Merger Price Effects." American Economic Review 101, no. 3: $45-50$.

Houde, Jean-Francois. 2012. "Spatial Differentiation and Vertical Mergers in Retail Markets for Gasoline." American Economic Review 102, no. 5: 2147-2182.

Huang, Kun and Kyle Stiegert. 2009. "Evaluating a Supermarket Merger Event: The Case of Copps and Kohl's in Madison WI,” FSRG Monograph Series, \#21

Hunter, Graeme, Gregory K. Leonard, and G. Steven Olley, (2008) “Merger

Retrospective Studies: A Review,” Antitrust Magazine, 23:1, 34-41.

Hüschelrath, Kai and Kathrin Müller. 2013. “The Competitive Effects of Firm Exit Evidence from the U.S. Airline Industry.” Economics of Transportation 2, 72-85.

Karikari, John Agyei, Stephen M. Brown, and Mehrzad Nadji. 2002. "The Union Pacific/Southern Pacific Railroads Merger: Effect of Trackage Rights on Rates." Journal Of Regulatory Economics 22, no. 3: 271-285.

Kim, E. Han, and Vijay Singal. 1993. "Mergers and Market Power: Evidence from the Airline Industry." American Economic Review 83, no. 3: 549-569

Kovacic, William. 2003. “The Modern Evolution of U.S. Competition Policy Enforcement Norms.” Antitrust Law Journal 71, no. 2: 377-478.

Kreisle, Nicholas. 2013. "Merger Policy at the Margin: Western Refineries Acquisition of Giant Industries,” FTC Bureau of Economics Working Paper \#319 
Krishnan, Ranjani. 2001. "Market Restructuring and Pricing in the Hospital Industry." Journal Of Health Economics 20, no. 2: 213-237.

Kwoka, John. 2013. “Does Merger Control Work? A Retrospective on U.S. Enforcement Actions and Merger Outcomes.” Antitrust Law Journal 78, no. 3: 619-650.

Kwoka, John, and Michael Pollitt. 2010. "Do Mergers Improve Efficiency? Evidence from Restructuring the US Electric Power Sector." International Journal of Industrial Organization 28, no. 6: 645-656.

Kwoka, John, and Evgenia Shumilkina. 2010. "The Price Effect of Eliminating Potential Competition: Evidence from an Airline Merger." Journal Of Industrial Economics 58, no. 4: 767-793.

Luo, Dan. 2014. “The Price Effects of the Delta/Northwest Airline Merger.” Review of Industrial Organization 44, 27-48.

McCabe, Mark J. 2002. "Journal Pricing and Mergers: A Portfolio Approach." American Economic Review 92, no. 1: 259-269

McCabe, Mark J. 2004. "Law Serials Pricing and Mergers: A Portfolio Approach." Contributions To Economic Analysis And Policy 3, no. 1: 1-29.

Montoriol-Garriga, Judit. 2008. "Bank mergers and lending relationships." mimeo Morrison, Steven A. 1996. "Airline Mergers: A Longer View." Journal Of Transport Economics And Policy 30, no. 3: 237-250

Pautler, Paul A. 2003. "Evidence on Mergers and Acquisitions." Antitrust Bulletin 48, no. 1: $119-221$

Perry, Martin K., and Robert H. Porter. 1985. "Oligopoly and the Incentive for Horizontal Merger." American Economic Review 75, no. 1: 219-227 
Peters, Craig. 2006. "Evaluating the Performance of Merger Simulation: Evidence from the U.S. Airline Industry." Journal of Law And Economics 49, no. 2: 627-649.

Prager, Robin A., and Timothy H. Hannan. 1998. "Do Substantial Horizontal Mergers Generate Significant Price Effects? Evidence from the Banking Industry." Journal of Industrial Economics 46, no. 4: 433-452

Sapienza, Paola. 2002. "The Effects of Banking Mergers on Loan Contracts." Journal of Finance 57, no. 1: 329-367.

Schumann, Laurence, James D. Reitzes, and Robert P. Rogers. 1997. "In the Matter of Weyerhaeuser Company: The Use of a Hold-Separate Order in a Merger with Horizontal and Vertical Effects." Journal Of Regulatory Economics 11, no. 3: 271-289.

Simpson, John, and Christopher Taylor. 2008. "Do Gasoline Mergers Affect Consumer Prices? The Marathon Ashland Petroleum and Ultramar Diamond Shamrock Transaction." Journal of Law And Economics 51, no. 1: 135-152.

Silvia, Louis, and Christopher T. Taylor. 2013. "Petroleum Mergers and Competition in the Northeast United States." International Journal of The Economics of Business 20, no. 1: 97124.

Taylor, Christopher T., and Daniel S. Hosken. 2007. "The Economic Effects of the Marathon-Ashland Joint Venture: The Importance of Industry Supply Shocks and Vertical Market Structure." Journal of Industrial Economics 55, no. 3: 419-451.

Tenn, Steven. 2011. "The Price Effects of Hospital Mergers: A Case Study of the SutterSummit Transaction." International Journal of The Economics of Business 18, no. 1: 65-82. Kriesle (2013) 
Thompson, Aileen. 2011. "The Effect of Hospital Mergers on Inpatient Prices: A Case Study of the New Hanover-Cape Fear Transaction." International Journal Of The Economics Of Business 18, no. 1: 91-101

Tremblay, Victor J., and Carol Horton Tremblay. 2005. The U.S. Brewing Industry: Data and Economic Analysis. MIT Press.: Cambridge and London.

Vita, Michael G., and Seth Sacher. 2001. "The Competitive Effects of Not-for-Profit Hospital Mergers: A Case Study." Journal of Industrial Economics 49, no. 1: 63-84.

United States v. Von’s Grocery Co., 384 U.S. 270 (1966).

United States v. Oracle Corp., 331 F. Supp. 2d 1098 (N.D. Calif. 2004).

U.S. Department of Justice (DOJ) 1968. Merger Guidelines. Washington, DC: DOJ.

---- 1982. Merger Guidelines. Washington, DC: DOJ.

---- 1984. Merger Guidelines. Washington, DC: DOJ.

U.S. Department of Justice (DOJ) and FTC. 1992. Horizontal Merger Guidelines. Washington, DC: DOJ and FTC.

----. 1997. Horizontal Merger Guidelines. Washington, DC: DOJ and FTC.

----. 2010. Horizontal Merger Guidelines. Washington, DC: DOJ and FTC.

----. 2012. Hart-Scott-Rodino Annual Report. Washington, DC: DOJ and FTC.

United States Government Accountability Office. 2004. Energy Markets: Effects of Mergers and Market Concentration in the U.S. Petroleum Industry.

----. 2009. Energy Markets: Estimates of the Effects of Mergers and Market Concentration on Wholesale Gasoline Prices.

Weinberg, Matthew. 2008. "The Price Effects of Horizontal Mergers." Journal of Competition Law And Economics 4, no. 2: 433-447. 
Werden, Gregory J., Andrew S. Joskow, and Richard L. Johnson. 1991. "The Effects of Mergers on Price and Output: Two Case Studies from the Airline Industry." Managerial And Decision Economics 12, no. 5: 341-352.

Williamson, O. E. 1968. "Economies as an antitrust defense: the welfare tradeoffs." American Economic Review 58, 18-36.

Winston, Clifford, Vikram Maheshri, and Scott M. Dennis. 2011. "Long-Run Effects of Mergers: The Case of U.S. Western Railroads." Journal Of Law And Economics 54, no. 2: 275304. 
Table 1: Estimated Price Effects of Consummated Horizontal Mergers in the Airline Industry

\begin{tabular}{|c|c|c|c|c|}
\hline Study & Study Description & Evidence on Enforcement Margin & Merger & Price Effects Reported \\
\hline \multirow{2}{*}{ Borenstein (1990) } & \multirow{2}{*}{$\begin{array}{l}\text { Compare how airline fares on routes directly } \\
\text { affected by merger compared to other routes } \\
\text { of similar length. }\end{array}$} & \multirow{2}{*}{$\begin{array}{l}\text { Author shows that Northwest and Republic had large } \\
\text { market shares at Minneapolis/St Paul, and TWA and } \\
\text { Ozark had very large shares in St. Louis. }\end{array}$} & Northwest/Republic (1986) & $9.5 \%$ \\
\hline & & & TWA/Ozark (1986) & unchanged \\
\hline \multirow{2}{*}{$\begin{array}{l}\text { Werden, Joskow, and } \\
\text { Johnson (1991) }\end{array}$} & \multirow{2}{*}{$\begin{array}{l}\text { Use a forecasting and backcasting method to } \\
\text { estimate merger price effects. }\end{array}$} & \multirow{2}{*}{$\begin{array}{l}\text { Authors state that, "DOJ (Department of Justice) } \\
\text { concluded that the two mergers would have significant } \\
\text { anticompetitive effects on many city pairs out of the } \\
\text { common hubs." }\end{array}$} & Northwest/Republic (1986) & $5.6 \%$ \\
\hline & & & TWA/Ozark (1986) & $1.1 \%$ \\
\hline $\begin{array}{l}\text { Kim and Singal } \\
\text { (1993) }\end{array}$ & $\begin{array}{l}\text { Compare merging firms prices to those on } \\
\text { routes not operated by either merging firm of } \\
\text { similar length. }\end{array}$ & $\begin{array}{l}\text { Authors state that the government did not challenge any } \\
\text { airline merger during this period (mergers were reviewed } \\
\text { by the Department of Transportation). This allows them } \\
\text { to measure price effects of relaxed antitrust policy. }\end{array}$ & 14 airline mergers & $\begin{array}{l}\text { Average merger effect: } 9.55 \% \text { price } \\
\text { increase, normal firms: } 3.25 \% \text { price } \\
\text { increase, financially distressed firm: } \\
26.35 \%\end{array}$ \\
\hline \multirow{3}{*}{ Morrison (1996) } & \multirow{3}{*}{$\begin{array}{l}\text { Estimates } 68 \text { separate quarterly regressions } \\
\text { using data on } 1000 \text { largest US city pairs, } \\
\text { examines how markets served by merging } \\
\text { parties evolved over time. Estimates separate } \\
\text { long and short run price effects }\end{array}$} & \multirow{3}{*}{$\begin{array}{l}\text { Describes competitive concerns regarding } \\
\text { Northwest/Republic and TWA/Ozark. Suggests at time } \\
\text { of merger USAir/Piedmont was less controversial } \\
\text { because they did not have overlapping hubs. }\end{array}$} & Northwest/Republic (1986) & Short Run: $-1.8 \%$, Long Run: 2.5\% \\
\hline & & & TWA/Ozark (1986) & Short Run: 4.4\%, Long Run: $-15.3 \%$ \\
\hline & & & & Short Run: 4.4\%, Long Run: $22.8 \%$ \\
\hline \multirow{5}{*}{ Peters (2006) } & \multirow{5}{*}{$\begin{array}{l}\text { Calculates the relative price change } \\
\text { associated with the merger on overlap routes } \\
\text { as the difference between the observed price } \\
\text { change and an average industry wide } \\
\text { percentage price change conditional on route } \\
\text { distance. }\end{array}$} & \multirow{5}{*}{$\begin{array}{l}\text { Author writes that, "antitrust enforcement in the industry } \\
\text { was relatively lax, with every proposed airline merger } \\
\text { receiving regulatory approval." }\end{array}$} & Northwest/Republic (1986) & $7.2 \%$ \\
\hline & & & TWA/Ozark (1986) & $16.0 \%$ \\
\hline & & & USAir/Piedmont & $20.3 \%$ \\
\hline & & & Delta/Western & $11.8 \%$ \\
\hline & & & Continental/Peoples Express & $29.4 \%$ \\
\hline $\begin{array}{l}\text { Kwoka and } \\
\text { Shumilkina (2010) }\end{array}$ & $\begin{array}{l}\text { Estimate merger price effect by comparing } \\
\text { prices to other firms on routes not served by } \\
\text { either USAir or Piedmont prior to merger. }\end{array}$ & $\begin{array}{l}\text { The author discusses the lax enforcement of airline } \\
\text { mergers during this time period and the two previous } \\
\text { studies of the merger finding price increases. }\end{array}$ & USAir/Piedomont & $\begin{array}{l}\text { Estimate prices rose } 10 \% \text { in overlap } \\
\text { markets and } 6 \% \text { where one of the two } \\
\text { firms was likely a potentially entrant }\end{array}$ \\
\hline $\begin{array}{l}\text { Huschelrath and } \\
\text { Muller (2013) }\end{array}$ & $\begin{array}{l}\text { Estimates the average price effect caused by } \\
\text { a horizontal merger (using information from } \\
\text { six mergers). }\end{array}$ & $\begin{array}{l}\text { No specific discussion of mergers being marginal, some } \\
\text { discussion of regulatory review. }\end{array}$ & $\begin{array}{l}\text { Delta/Northwest (2009), } \\
\text { Frontier/Midwest (2009), US } \\
\text { Airways/America West } \\
\text { (2005), American } \\
\text { Airlines/TWA (2001), } \\
\text { American Airlines/Reno Air } \\
\text { (1999), AirTran/Valujet } \\
\text { (1998) }\end{array}$ & $\begin{array}{l}\text { Estimate short-run price increase of } 5.6 \% \text {, } \\
\text { medium-run price increase of } 4.7 \% \text {, and } \\
\text { long-run price effect of } 2.7 \% \text { (but not } \\
\text { statistically different than zero). }\end{array}$ \\
\hline Luo (2013) & $\begin{array}{l}\text { Estimates price effects of merger holding } \\
\text { competition from other firms constant. }\end{array}$ & $\begin{array}{l}\text { States that DOJ reviewed merger but allowed because of } \\
\text { minimal overlap and likely merger efficiencies. }\end{array}$ & Delta/Northwest (2009) & $\begin{array}{l}\text { No price effect on non-stop routes, } 2.3 \% \\
\text { price increase on connecting routes. }\end{array}$ \\
\hline
\end{tabular}


Table 2: Estimated Price Effects of Consummated Horizontal Mergers in the Banking Industry

\begin{tabular}{|c|c|c|c|c|}
\hline Study & Study Description & Evidence on Enforcement Margin & Merger & Price Effects Reported \\
\hline $\begin{array}{l}\text { Prager and Hannan } \\
\text { (1998) }\end{array}$ & $\begin{array}{l}\text { Study estimates how interest rates paid to } \\
\text { consumers on saving accounts changed in } \\
\text { markets affected by mergers relative to } \\
\text { unaffected markets }\end{array}$ & $\begin{array}{l}\text { Limit attention to significant horizontal mergers (those } \\
\text { leading to relatively large changes in market } \\
\text { concentration). }\end{array}$ & $\begin{array}{l}7 \text { mergers taking place } \\
\text { between } 1992 \text { and } 1994 .\end{array}$ & $\begin{array}{l}\text { NOW Accounts: }-17.7 \% \text {; Money Market } \\
\text { Accounts: }-9.5 \% \text {, 3-Month CDs: }-1.7 \% \text {. }\end{array}$ \\
\hline Sapienza (2002) & $\begin{array}{l}\text { Estimates how firms loan prices changed } \\
\text { following a merger as a function of the } \\
\text { relative size of the merger. }\end{array}$ & $\begin{array}{l}\text { No specific discussion of regulatory treatment of specific } \\
\text { mergers. }\end{array}$ & $\begin{array}{l}138 \text { bank mergers taking } \\
\text { place in Italy between } 1989 \\
\text { and } 1995 .\end{array}$ & $\begin{array}{l}\text { Estimate that mergers of firms of banks } \\
\text { with small market shares lowered loan } \\
\text { rates (typical reduction } 41 \text { basis points), } \\
\text { while mergers of firms with large market } \\
\text { shares increase loan rates (as much as } 80 \\
\text { basis points). }\end{array}$ \\
\hline $\begin{array}{l}\text { Focarelli and Panetta } \\
\text { (2003) }\end{array}$ & $\begin{array}{l}\text { Study estimates how interest rates paid to } \\
\text { consumers on saving accounts changed in } \\
\text { markets affected by mergers relative to } \\
\text { unaffected markets. Study estimates short } \\
\text { and long run price effect of mergers. }\end{array}$ & $\begin{array}{l}\text { Estimate the price effects of all mergers in data, } \\
\text { however, the authors also separately examine a sample } \\
\text { of substantial mergers (those generating a large change } \\
\text { in market concentration). }\end{array}$ & $\begin{array}{l}\text { Mergers taking place in Italy } \\
\text { between } 1990 \text { and } 1998 .\end{array}$ & $\begin{array}{l}\text { All Mergers: Short Run Effect: }-13.5 \% \text {, } \\
\text { Long Run Effect: } 12.6 \% \text {; Substantial } \\
\text { Mergers: Short Run Effect: }-19 \% \text {, Long } \\
\text { Run Effect: } 10.7 \%\end{array}$ \\
\hline $\begin{array}{l}\text { Calomiris and } \\
\text { Pornrojnangkool (2005) }\end{array}$ & $\begin{array}{l}\text { Estimates how loan prices changed in } \\
\text { markets affected by the merger relative to } \\
\text { other similar markets. }\end{array}$ & $\begin{array}{l}\text { Banks were required to divest branch locations. Despite } \\
\text { divestitures, the merger substanitally increased } \\
\text { concentration for medium sized firms needing bank } \\
\text { loans. }\end{array}$ & $\begin{array}{l}\text { Merger of Fleet and Bank } \\
\text { Boston, } 1999 .\end{array}$ & $\begin{array}{l}\text { Medium-Sized banks loan rates increased } \\
\text { between } 80 \text { and } 100 \text { basis points for } \\
\text { customers in New England. }\end{array}$ \\
\hline $\begin{array}{l}\text { Garmaise and } \\
\text { Moskowiotz (2006) }\end{array}$ & $\begin{array}{l}\text { Estimates how local loan prices are affected } \\
\text { by mergers as a function of the relative size } \\
\text { of the merger. }\end{array}$ & $\begin{array}{l}\text { Examine large mergers of financially healthy competing } \\
\text { banks. No specific discussion of antitrust review of } \\
\text { mergers studied. }\end{array}$ & $\begin{array}{l}80 \text { Large Bank Mergers } \\
\text { taking Place between } 1992 \\
\text { and } 1999 .\end{array}$ & $\begin{array}{l}\text { Find that the largest bank mergers could } \\
\text { increase loan prices by about } 40.1 \text { basis } \\
\text { points. }\end{array}$ \\
\hline $\begin{array}{l}\text { Montoriol-Garriga } \\
(2008)\end{array}$ & $\begin{array}{l}\text { Estimates how firms estimated loan price } \\
\text { changes as a result of horizontal mergers in } \\
\text { markets of different concentration levels. }\end{array}$ & $\begin{array}{l}\text { No specific discussion of regulatory treatment of specific } \\
\text { mergers. }\end{array}$ & Bank Mergers in Spain. & $\begin{array}{l}\text { Estimate that loan prices fall following all } \\
\text { mergers, however, prices fall less in } \\
\text { markets experiencing larger mergers. } \\
\text { Estimated price decreases vary from } 0 \text { to } \\
20 \text { basis points. }\end{array}$ \\
\hline $\begin{array}{l}\text { Allen, Clark, and Houde } \\
\text { (2013) }\end{array}$ & $\begin{array}{l}\text { Estimate how mortgage prices change in } \\
\text { markets affected by the merger relative to } \\
\text { markets where the merging firms did not } \\
\text { compete. }\end{array}$ & $\begin{array}{l}\text { Authors provide a generall discussion of how the } \\
\text { Canadian mortgage market has become relatively } \\
\text { concentrated, however, specific transaction is not } \\
\text { described in detail. }\end{array}$ & A banking merger in Canada. & $\begin{array}{l}\text { Estimate mortgage rates increase between } \\
5.7 \text { and } 7.39 \text { basis points. }\end{array}$ \\
\hline
\end{tabular}


Table 3: Estimated Price Effects of Consummated Horizontal Mergers in the Hospital Industry

\begin{tabular}{|c|c|c|c|c|}
\hline Study & Study Description & Evidence on Enforcement Margin & Merger & Price Effects Reported \\
\hline $\begin{array}{l}\text { Connor, Feldman, } \\
\text { Dowd (1998) }\end{array}$ & $\begin{array}{l}\text { Study estimates how merging hosptials prices } \\
\text { changed relative to non-merging hospitals. }\end{array}$ & $\begin{array}{l}\text { s Does not provide information on individual mergers } \\
\text { studied. }\end{array}$ & $\begin{array}{l}112 \text { Mergers taking place } \\
\text { between } 1986 \text { and } 1994 .\end{array}$ & $\begin{array}{l}\text { Estimate that, on average, merging } \\
\text { hospitals prices fell by about } 5 \% \text {. Find } \\
\text { evidence that prices fell less in more } \\
\text { concentrated markets. }\end{array}$ \\
\hline Krishnan (2001) & $\begin{array}{l}\text { Estimates how the prices of high-volume } \\
\text { procedures at hospitals directly affected by } \\
\text { mergers changed relative to hospital in the } \\
\text { same market and other markets. }\end{array}$ & $\begin{array}{l}\text { Does not provide detailed information on individual } \\
\text { mergers studied. }\end{array}$ & $\begin{array}{l}\text { Examine change in price of } \\
22 \text { Ohio hospitals affected by } \\
\text { mergers in } 1994 \text { or } 1995 .\end{array}$ & $\begin{array}{l}\text { Estimates the price of high volume } \\
\text { procedures increased by } 16.5 \% \text { at merging } \\
\text { hospitals. }\end{array}$ \\
\hline Vita and Sacher (2001) & $\begin{array}{l}\text { Study estimates how merging hospital prices } \\
\text { changed relative to a control group. }\end{array}$ & $\begin{array}{l}\text { Authors state that, "Had the FTC had the opportunity to } \\
\text { seek a preliminary injunction in this case, it would have } \\
\text { done so." }\end{array}$ & $\begin{array}{l}\text { Dominican Santa Cruz } \\
\text { Hospital's acqusition of AMI } \\
\text { Community Hosiptal (1990). }\end{array}$ & $\begin{array}{l}\text { Estimate Dominican price rose by } 23 \% \\
\text { and AMI price rose by } 17 \% \text {. }\end{array}$ \\
\hline Dafny (2009) & $\begin{array}{l}\text { Study estimates how rival hospitals changed } \\
\text { price following a merger. }\end{array}$ & $\begin{array}{l}\text { Does not provide information on individual mergers } \\
\text { studied. }\end{array}$ & $\begin{array}{l}\text { Uses a sample of many } \\
\text { mergers taking place between } \\
1989 \text { and } 1996\end{array}$ & $\begin{array}{l}\text { Estimate that rival hosptials increase by } \\
\text { roughly } 40 \% \text {. }\end{array}$ \\
\hline \multirow[b]{2}{*}{$\begin{array}{l}\text { Haas-Wilson and } \\
\text { Garmon (2011) }\end{array}$} & \multirow[b]{2}{*}{$\begin{array}{l}\text { Study estimates how merging hospital prices } \\
\text { changed relative to a control group. }\end{array}$} & Merger of only 2 hospitals in Waukegan, Illinois. & $\begin{array}{l}\text { Merger of St. Therese and } \\
\text { Victory hospitals (2000). }\end{array}$ & $\begin{array}{l}\text { Estimated price effects vary by control } \\
\text { group, insurer, and estimation method } \\
(-20 \%-29 \%) . \text { In most cases prices } \\
\text { decreased. }\end{array}$ \\
\hline & & $\begin{array}{l}\text { Merger challenged by FTC four years after merger } \\
\text { consummation. }\end{array}$ & $\begin{array}{l}\text { Merger of Evanston } \\
\text { Northwestern Healtcare } \\
\text { Corporation and Highland } \\
\text { Park Hospital (2000). }\end{array}$ & $\begin{array}{l}\text { Estimated price effects vary by control } \\
\text { group, insurer, and estimation method } \\
(-2 \%-80 \%) \text {. The overwhelming majority } \\
\text { of estimated price increase were positive, } \\
\text { economically and statistically significant. }\end{array}$ \\
\hline Tenn (2011) & $\begin{array}{l}\text { Study estimates how merging hospital prices } \\
\text { changed relative to a control group. }\end{array}$ & $\begin{array}{l}\text { State of California unsuccesfully attempted to block } \\
\text { merger. }\end{array}$ & $\begin{array}{l}\text { Sutter's purchase of Summit } \\
\text { Hospital (1999). }\end{array}$ & $\begin{array}{l}\text { Large price increases for Summit varying } \\
\text { by insurer and estimation method ( } 23 \%- \\
50 \% \text { ). No systematic evidence of a price } \\
\text { increase or decrease for Sutter owned } \\
\text { hospital. }\end{array}$ \\
\hline Thompson (2011) & $\begin{array}{l}\text { Study estimates how merging hospital prices } \\
\text { changed relative to a control group. }\end{array}$ & $\begin{array}{l}\text { Merging hospitals much closer to each other than rival } \\
\text { hospitals. }\end{array}$ & $\begin{array}{l}\text { New Hannover Regional } \\
\text { Medical Center acquisition } \\
\text { of Columbia Cape Fear } \\
\text { Memorial Hospital (1998). }\end{array}$ & $\begin{array}{l}\text { Estimated price effects vary dramatically } \\
\text { by insurer (-30\% - 65\%). Two insurers } \\
\text { experienced a price increase, one a price } \\
\text { decrease, and one little meaningful change } \\
\text { in price relative to the control group. }\end{array}$ \\
\hline
\end{tabular}


Table 4: Estimated Price Effects of Consummated Horizontal Mergers in the Petroleum Industr

\begin{tabular}{|c|c|c|c|c|}
\hline Study & Study Description & Evidence on Enforcement Margin & Merger & Price Effects Reported \\
\hline \multirow{8}{*}{ GAO (2004) } & \multirow{8}{*}{$\begin{array}{l}\text { The study estimates the change in wholesale } \\
\text { prices due to merger. Separate price effects } \\
\text { estimated for each specification of gasoline } \\
\text { and branded and unbranded wholesale price. }\end{array}$} & \multirow{8}{*}{$\begin{array}{l}\text { Mergers selected because of, "their transaction size, } \\
\text { FTC's review of them, or concerns expressed by some } \\
\text { industry participants and state officials we [GAO] } \\
\text { interviewed." }\end{array}$} & $\begin{array}{l}\text { Tosco's purchase of Unocal } \\
\text { refinery in } 1997 .\end{array}$ & $\begin{array}{l}\text { Branded CARB Gas: } 6.8 \text { cpg, Unbranded } \\
\text { CARB Gas: }-1.58 \text { cpg }\end{array}$ \\
\hline & & & $\begin{array}{l}\text { UDS purchase of Total in } \\
1997 .\end{array}$ & $\begin{array}{l}\text { Branded Conventional Gas: }-.89 \text { cpg, } \\
\text { Unbranded Conventional Gas: }-1.25 \text { cpg }\end{array}$ \\
\hline & & & $\begin{array}{l}\text { Joint venture between } \\
\text { Marathon and Ashland } \\
\text { Petroleum in } 1998 .\end{array}$ & $\begin{array}{l}\text { Branded Conventional Gas: .7 cpg, } \\
\text { Unbranded Conventional Gas: .39 cpg, } \\
\text { Branded Reformulated Gas: .71cpg, } \\
\text { Unbranded Reformulated Gas: } .86 \mathrm{cpg} \\
\end{array}$ \\
\hline & & & $\begin{array}{l}\text { Shell Texaco I (Creation of } \\
\text { Equilon) } 1998\end{array}$ & $\begin{array}{l}\text { Branded Conventional Gas: } .99 \text { cpg, } \\
\text { Unbranded Conventional Gas: } 1.13 \text { cpg, } \\
\text { Branded CARB Gas: }-.69 \text { cpg, Unbranded } \\
\text { CARB Gas: }-.24 \text { cpg }\end{array}$ \\
\hline & & & $\begin{array}{l}\text { Shell Texaco II (Creation of } \\
\text { Motiva) } 1998\end{array}$ & $\begin{array}{l}\text { Branded Convnetional Gas: }-1.77 \text { cpg, } \\
\text { Unbranded Conventional Gas: }-1.24 \mathrm{cpg}, \\
\text { Branded Reformulated Gas: .39cpg, } \\
\text { Unbranded Reformulated Gas: .09 cpg }\end{array}$ \\
\hline & & & ВР-Атосо 1998 & $\begin{array}{l}\text { Branded Conventional Gas: .4 cpg, } \\
\text { Unbranded Conventional Gas: .97, } \\
\text { Branded Reformulated Gas: .55cpg, } \\
\text { Unbranded Reformulated Gas: .4 cpg }\end{array}$ \\
\hline & & & MAP-UDS & $\begin{array}{l}\text { Branded Conventional Gas: } 1.38 \text { cpg, } \\
\text { Unbranded Conventional Gas: } 2.63 \text { cpg }\end{array}$ \\
\hline & & & Exxon-Mobil 2000 & $\begin{array}{l}\text { Branded Conventional Gas: } 3.71 \mathrm{cpg} \text {, } \\
\text { Unbranded Conventional Gas: } 5.00 \mathrm{cpg}, \\
\text { Branded Reformulated Gas: } 1.61 \mathrm{cpg}, \\
\text { Unbranded Reformulated Gas: } 1.01 \mathrm{cpg}\end{array}$ \\
\hline $\begin{array}{l}\text { Chouinard and Perloff } \\
\text { (2007) }\end{array}$ & $\begin{array}{l}\text { Estimates a price equation separately for } \\
\text { retail and wholesale gasoline prices. Using } \\
\text { this model they estimate merger price effects } \\
\text { of the } 31 \text { mergers. The authors report the } \\
\text { mean and range of estimated merger effects } \\
\text { rather than seperate price effects by merger. }\end{array}$ & $\begin{array}{l}\text { No information providing as to whether mergers were } \\
\text { marginal. }\end{array}$ & $\begin{array}{l}6 \text { refinery and } 25 \text { retail } \\
\text { mergers taking place between } \\
1989 \text { and } 1998 .\end{array}$ & $\begin{array}{l}\text { Retail price: mean refining merger price } \\
\text { effect: } .43 \mathrm{cpg} \text {, mean retailing merger } \\
\text { price effect: }-.04 \mathrm{cpg} \text {, Wholesale price: } \\
\text { mean refining merger effect: } .57 \mathrm{cpg} \text {, } \\
\text { mean retailing merger effect: }-.06 .\end{array}$ \\
\hline $\begin{array}{l}\text { Taylor and Hosken } \\
\text { (2007) }\end{array}$ & $\begin{array}{l}\text { Estimates change in wholesale and retail } \\
\text { gasoline prices prices resulting from the } \\
\text { merger in four markets. }\end{array}$ & $\begin{array}{l}\text { A press report stated that the FTC reviewed and allowed } \\
\text { the merger without conditions. }\end{array}$ & $\begin{array}{l}\text { Joint venture between } \\
\text { Marathon and Ashland } \\
\text { Petroleum in } 1998 .\end{array}$ & $\begin{array}{l}\text { Wholesale price increases in } 2 / 4 \text { markets. } \\
\text { Retail changes in only } 1 \text { of those } 2 \text {, likely } \\
\text { due to a cost shock. }\end{array}$ \\
\hline $\begin{array}{l}\text { Simpson and Taylor } \\
\text { (2008) }\end{array}$ & $\begin{array}{l}\text { Estimates change in retail gasoline price } \\
\text { resulting from transaction in } 6 \text { affected } \\
\text { markets in U.S. Midwest. }\end{array}$ & $\begin{array}{l}\text { No challenge. Authors argue that the merger increased } \\
\text { market concentration more than many other prominent } \\
\text { mergers in petroleum industry. }\end{array}$ & $\begin{array}{l}\text { Marathon Ashland Petroleum } \\
\text { (MAP) aquires Michigan } \\
\text { Assets of Ultramar Diamond } \\
\text { Shamrock (UDS) (1999) }\end{array}$ & $\begin{array}{l}\text { No meaningful change in retail gasoline } \\
\text { prices. }\end{array}$ \\
\hline
\end{tabular}


Table 4: Estimated Price Effects of Consummated Horizontal Mergers in the Petroleum Industr

\begin{tabular}{|c|c|c|c|c|}
\hline Study & Study Description & Evidence on Enforcement Margin & Merger & Price Effects Reported \\
\hline \multirow{7}{*}{ GAO (2009) } & \multirow{7}{*}{$\begin{array}{l}\text { Estimates the price effects of } 7 \text { petroleum } \\
\text { mergers taking place between } 2001 \text { and } \\
\text { 2005. All specifications of gas pooled in a } \\
\text { single regression. }\end{array}$} & \multirow{7}{*}{$\begin{array}{l}\text { Mergers selected into study if: value was greater than } \\
\$ 200 \text { million, occurred between } 2000 \text { and 2007, and if } \\
\text { adequate price data was available. }\end{array}$} & $\begin{array}{l}\text { Chevron/Texaco (2000): Oil } \\
\text { and Gas Reserves }\end{array}$ & Results not statistically significant \\
\hline & & & $\begin{array}{l}\text { Phillips Petroleum } \\
\text { Company/Tosco (2001): } 8 \\
\text { refineries and appoximately } \\
6,400 \text { retail gasoline stations. }\end{array}$ & Results not statistically significant \\
\hline & & & $\begin{array}{l}\text { Valero/UDS (2001): } 7 \\
\text { refineries and approximately } \\
5,000 \text { retail gasoline stations. }\end{array}$ & $\begin{array}{l}\text { Branded Gasoline Price: } 1.06 \text { cpg, } \\
\text { Unbranded Gasoline Price: not statistically } \\
\text { significant. }\end{array}$ \\
\hline & & & $\begin{array}{l}\text { Royal Dutch Shell/Texaco } \\
\text { (2001): Texaco's share of } \\
\text { Motiva and Equilon } \\
\text { downstream joint ventures. }\end{array}$ & Results not statistically significant \\
\hline & & & $\begin{array}{l}\text { Phillips Petroleum } \\
\text { Company/Conocco } \\
\text { (2001):Oil and Gas Reserves, } \\
\text { refining and marketing } \\
\text { assets. }\end{array}$ & $\begin{array}{l}\text { Branded Gasoline Price: -1.64, Unbranded } \\
\text {, Gasoline Price: }-1.14\end{array}$ \\
\hline & & & $\begin{array}{l}\text { Premcor/Williams (2002): } 1 \\
\text { refinery. }\end{array}$ & Results not statistically significant \\
\hline & & & $\begin{array}{l}\text { Valero/Premcor (2005): } 4 \\
\text { refineries. }\end{array}$ & $\begin{array}{l}\text { Branded Gasoline Price: not statistically } \\
\text { significant, Unbranded Gasoline Price: } \\
1.13 \mathrm{cpg}\end{array}$ \\
\hline \multirow[b]{2}{*}{$\begin{array}{l}\text { Hosken, Silvia, and } \\
\text { Taylor (2011) }\end{array}$} & \multirow{2}{*}{$\begin{array}{l}\text { Estimates change in wholesale and retail } \\
\text { gasoline prices resulting from merger. } \\
\text { Authors examine how a reduction in market } \\
\text { concentration resulting from a sale of a } \\
\text { refinery by affected gasoline prices in San } \\
\text { Francisco. This merger essentially returned } \\
\text { market concentration to the pre- } \\
\text { Tosco/Unocal Level. }\end{array}$} & $\begin{array}{l}\text { Two previous studies found this merger increased some } \\
\text { wholesale prices. }\end{array}$ & $\begin{array}{l}\text { Tosco's purchase of Unocal } \\
\text { refinery in } 1997 .\end{array}$ & $\begin{array}{l}\text { Branded wholesale prices decrease by } 1-3 \\
\text { cpg, unbranded prices may have increased } \\
\text { by } 1 \mathrm{cpg} \text {, and retail prices were essentially } \\
\text { unchanged. }\end{array}$ \\
\hline & & $\begin{array}{l}\text { Merger reduced market concentation (not a marginal } \\
\text { merger). }\end{array}$ & $\begin{array}{l}\text { UDS purchase of Tosco } \\
\text { refinery in } 2000 .\end{array}$ & $\begin{array}{l}\text { Branded and unbranded wholesale prices } \\
\text { decreased between } 2-5 \text { cpg. Evidence on } \\
\text { retail pricing is mixed varying from no } \\
\text { change to a } 3 \text { cpg increase. }\end{array}$ \\
\hline Houde (2013) & $\begin{array}{l}\text { Estimates change in retail gasoline price } \\
\text { relative to a comparison group. }\end{array}$ & $\begin{array}{l}\text { Canadian Competition Bureau reviewed merger and } \\
\text { allowed it to proceed. }\end{array}$ & $\begin{array}{l}\text { Ultramar's } 1997 \text { purchase of } \\
12 \text { Sunoco gasoline stations } \\
\text { in Quebec City, Quebec. }\end{array}$ & $\begin{array}{l}\text { Prices estimated to increase between } .15 \\
\text { and } .45 \text { cents-per-liter depending on } \\
\text { sample. }\end{array}$ \\
\hline Kreisle (2013) & $\begin{array}{l}\text { Estimates change in wholesale and retail gas } \\
\text { and diesel prices due to merger. }\end{array}$ & $\begin{array}{l}\text { The FTC unsuccessfully attempted to challenge this } \\
\text { merger. }\end{array}$ & $\begin{array}{l}\text { Western Refining's purchase } \\
\text { of Giant Industries in } 2007 .\end{array}$ & $\begin{array}{l}\text { Estimates depend on control group and } \\
\text { price measure (- } 12 \text { to } 3 \text { cpg). Most are } \\
\text { negative and statistically significantly } \\
\text { different than zero. }\end{array}$ \\
\hline
\end{tabular}


Table 4: Estimated Price Effects of Consummated Horizontal Mergers in the Petroleum Industr

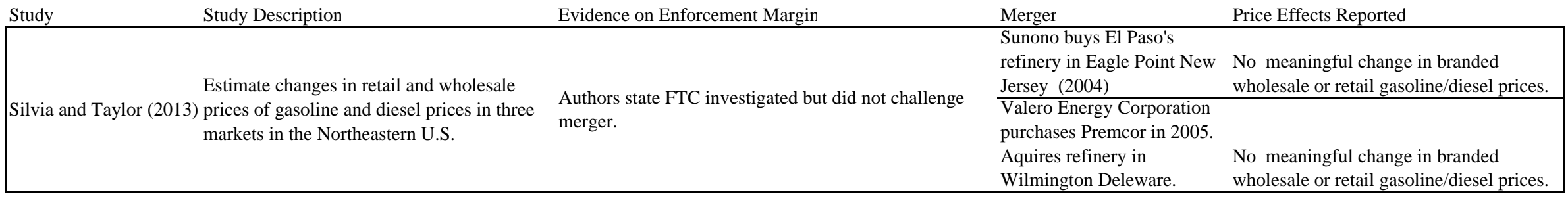


Table 5: Estimated Price Effects of Consummated Horizontal Mergers in Other Industries

\begin{tabular}{|c|c|c|c|c|}
\hline Study & Study Description & Evidence on Enforcement Margin & Merger & Price Effects Reported \\
\hline Barton and Sherman (1984) & $\begin{array}{l}\text { Estimates how prices changed after the } \\
\text { merger relative to substitute brands not } \\
\text { involved in merger. }\end{array}$ & $\begin{array}{l}\text { FTC sued Xidex after mergers were consummated. The } \\
\text { suit settled after Xidex aggreed to a divestiture and } \\
\text { licensing agreements. }\end{array}$ & $\begin{array}{l}\text { Two microfilm mergers } \\
\text { involving Xidex Corporation. }\end{array}$ & $\begin{array}{l}\text { First merger raised prices by } 11 \text { percent, } \\
\text { the second by } 23 \text { percent. }\end{array}$ \\
\hline $\begin{array}{l}\text { Schumann, Reitzes, and Rogers } \\
\text { (1997) }\end{array}$ & $\begin{array}{l}\text { Examine how the prices of cardboard and } \\
\text { cardboard inputs changed following a merger } \\
\text { holding cost and demand factors constant. }\end{array}$ & $\begin{array}{l}\text { FTC sued and failed to block merger, however, market } \\
\text { unconcentrated by current standards (post-merger HHI } \\
\text { of 1166). }\end{array}$ & $\begin{array}{l}\text { Weyerhaueser purchase of west } \\
\text { coast assets of Menasha in } 1980 . \\
\text { Both produced cardboard and } \\
\text { cardboard inputs. }\end{array}$ & $\begin{array}{l}\text { Estimate that cardboard box prices fell } \\
\text { between } 10 \% \text { and } 13 \% \text {. No significant } \\
\text { change in cardboard input prices. }\end{array}$ \\
\hline Karikari, Brown, Nadji (2002) & $\begin{array}{l}\text { Examine various shipping prices for the Salt } \\
\text { Lake City market following the merger. Study } \\
\text { focuses on examining the efficacy of the } \\
\text { merger remedy: how did the prices of } \\
\text { consumers who previously were only served } \\
\text { by UP and SP change following the merger. }\end{array}$ & $\begin{array}{l}\text { Department of Justice forced the merging parties to } \\
\text { allow rivals access to tracks on all routes where only UP } \\
\text { and SP operated prior to the merger. }\end{array}$ & $\begin{array}{l}1996 \text { merger of Union Pacific } \\
\text { and Southern Pacific railroads. }\end{array}$ & $\begin{array}{l}\text { All statistically significant price effects are } \\
\text { negative, vary from }-8 \% \text { to }-26 \% \text {. }\end{array}$ \\
\hline McCabe (2002) & $\begin{array}{l}\text { Estimates how prices of merging academic } \\
\text { journals changed relative to journals owned } \\
\text { by other publishers. Some mergers occurred } \\
\text { concurrently. These are not individually } \\
\text { identified. }\end{array}$ & None mentioned. & Seven academic journal mergers. & $\begin{array}{l}\text { Reed Elsevier/Pergamon: 10\%; Wolters } \\
\text { Kluwert/Lippincott: 5\%; Wolters } \\
\text { Kluwer/Thomson/Waverly/Pelnum: 3-6\%; } \\
\text { Harcourt/Churchill Livingstone/Mosby: 3- } \\
\text { 6\% }\end{array}$ \\
\hline McCabe (2004) & $\begin{array}{l}\text { Estimates how prices of merging firms serials } \\
\text { changed relative to other serials. }\end{array}$ & $\begin{array}{l}\text { At least one of the mergers (Thomson's purchase of } \\
\text { West) was reviewed by DOJ. }\end{array}$ & $\begin{array}{l}\text { Six mergers of law serial } \\
\text { publishers, one involved a partial } \\
\text { divestiture. }\end{array}$ & $\begin{array}{l}\text { Effects estimated separately for acquiring } \\
\text { and acquired firms' serials. } 7 / 9 \text { reported } \\
\text { estimates are positive, ranging between } 1 \\
\text { and } 21 \% \text {. Divested journals prices rose by } \\
15 \% \text {. }\end{array}$ \\
\hline $\begin{array}{l}\text { Chandra and Collard-Wexler } \\
\text { (2009) }\end{array}$ & $\begin{array}{l}\text { Changes in circulation and advertising prices } \\
\text { of papers involved in mergers are compared } \\
\text { to changes for other newspapers. }\end{array}$ & $\begin{array}{l}\text { Authors describe how the mergers significantly } \\
\text { increased market concentration, including multimarket } \\
\text { contact. }\end{array}$ & $\begin{array}{l}\text { Several Canadian newspaper } \\
\text { mergers }\end{array}$ & $\begin{array}{l}\text { No significant changes in advertising or } \\
\text { circulation prices. }\end{array}$ \\
\hline Huang and Steigert (2009) & $\begin{array}{l}\text { Estimates how prices of merging stores in } \\
\text { Madison changed relative to stores in Green } \\
\text { Bay. }\end{array}$ & Assets had value below HSR threshholds. & $\begin{array}{l}\text { Retail supermarket merger in } \\
\text { Madison, WI }\end{array}$ & $\begin{array}{l}\text { No significant price changes } 6 \text { months } \\
\text { following merger. Two years after merger: } \\
\text { price increases of between } 2 \text { and } 5 \% \text {. }\end{array}$ \\
\hline \multirow{7}{*}{ Ashenfelter and Hosken (2010) } & \multirow{7}{*}{$\begin{array}{l}\text { Estimates how prices of product's owned by } \\
\text { merging firms increased after the mergers } \\
\text { relative to private label prices. }\end{array}$} & \multirow{7}{*}{$\begin{array}{l}\text { Each merger involved large firms in already } \\
\text { concentrated industries. FTC required a change in } \\
\text { GMI/Chex merger agreement and required } \\
\text { Guinness/Grand Metropolitan to divest a Scotch and a } \\
\text { gin brand. }\end{array}$} & $\begin{array}{l}\text { Pennzoil/Quaker State (Motor } \\
\text { Oil) }\end{array}$ & $5.0 \%$ \\
\hline & & & General Mills/Chex (Cereal) & $3.2 \%$ \\
\hline & & & $\begin{array}{l}\text { P\&G/Tambrands (Feminine } \\
\text { Hygiene Products) }\end{array}$ & $7.0 \%$ \\
\hline & & & Aroura/P\&G (Breakfast Syrup) & $0.4 \%$ \\
\hline & & & $\begin{array}{c}\text { Guinness/Grand Metropolitan } \\
\text { Scotch }\end{array}$ & $7.1 \%$ \\
\hline & & & Gin & $2.2 \%$ \\
\hline & & & Vodka & $1.1 \%$ \\
\hline
\end{tabular}


Table 5: Estimated Price Effects of Consummated Horizontal Mergers in Other Industries

\begin{tabular}{|c|c|c|c|c|}
\hline Study & Study Description & Evidence on Enforcement Margin & Merger & Price Effects Reported \\
\hline $\begin{array}{l}\text { Dafny, Duggan, and } \\
\text { Ramanarayanan (2011) }\end{array}$ & $\begin{array}{l}\text { Estimates how predicted increases in } \\
\text { concentration due to merger changed } \\
\text { insurance premiums. }\end{array}$ & $\begin{array}{l}\text { Investigated by DOJ, and approved after Aetna divested } \\
\text { Texas plans. }\end{array}$ & $\begin{array}{l}\text { Health insurer merger involving } \\
\text { Aetna and Prudential }\end{array}$ & $\begin{array}{l}\text { The merger is predicted to increase prices } \\
\text { by } .5 \% \text { in the average market. }\end{array}$ \\
\hline \multirow{2}{*}{$\begin{array}{l}\text { Winston, Maheshri, and Dennis } \\
\text { (2011) }\end{array}$} & \multirow{2}{*}{$\begin{array}{l}\text { Examine how the prices of shipping grain for } \\
\text { export changed following the mergers using } \\
\text { both a reduced form and structural model. }\end{array}$} & $\begin{array}{l}\text { Describe merger as having both vertical and horizontal } \\
\text { components. No discussion of whether the merger was } \\
\text { on the enforcement margin. }\end{array}$ & $\begin{array}{l}1995 \text { merger of Burlington } \\
\text { Northern and Santa Fe railroads. }\end{array}$ & $\begin{array}{l}\text { Prices rose in years directly following the } \\
\text { merger, but eventually fell to pre-merger } \\
\text { levels. }\end{array}$ \\
\hline & & $\begin{array}{l}\text { Department of Justice forced the merging parties to } \\
\text { allow rivals access to tracks on all routes where only UP } \\
\text { and SP operated prior to the merger. }\end{array}$ & $\begin{array}{l}1996 \text { merger of Union Pacific } \\
\text { and Southern Pacific railroads. }\end{array}$ & $\begin{array}{l}\text { Prices rose in years directly followign } \\
\text { merger, but eventually fell to pre-merger } \\
\text { levels. }\end{array}$ \\
\hline Chone and Linnemer (2012) & $\begin{array}{l}\text { Estimates changes in rival prices relative to } \\
\text { various control groups. }\end{array}$ & $\begin{array}{l}\text { Merger resulted in large increases in concentration, } \\
\text { however, approved by regulator with only behavioral } \\
\text { remedies. }\end{array}$ & $\begin{array}{l}\text { The merger of two large parking } \\
\text { lot companies operating in Paris, } \\
\text { France in } 2000 .\end{array}$ & $\begin{array}{l}\text { Rivals increase price by about } 3 \% \text {, } \\
\text { however, the estimates are sensitive to } \\
\text { control measure. }\end{array}$ \\
\hline $\begin{array}{l}\text { Hosken, Olsen, and Smith } \\
\text { (2012) }\end{array}$ & $\begin{array}{l}\text { Estimate price effects sepatately by merger. } \\
\text { Price effects identified by price change } \\
\text { relative to various control groups from } \\
\text { regions unaffected by the mergers. }\end{array}$ & $\begin{array}{l}\text { Authors analyze mergers both likely and unlikely to be } \\
\text { on the enforcement margin. }\end{array}$ & $\begin{array}{l}14 \text { retail supermarket mergers } \\
\text { taking place in } 2007 \text { or } 2008\end{array}$ & $\begin{array}{l}\text { Prices fell following five mergers (-2\% to } \\
8 \% \text { ), rose following five mergers ( } 2 \%- \\
6 \% \text { ), and were unchanged following four. }\end{array}$ \\
\hline Aguzzoni et al. (2013) & $\begin{array}{l}\text { Estimates how prices changed in regions with } \\
\text { overlap relative to other regions. }\end{array}$ & $\begin{array}{l}\text { UK Competition Commission investigaged the merger } \\
\text { and approved with no modifications. }\end{array}$ & U.K. book retailers & No significant change \\
\hline Allain et al. (2013) & $\begin{array}{l}\text { Estimates changes in rival prices relative to a } \\
\text { control groups. }\end{array}$ & $\begin{array}{l}\text { Merger was investigated by antitrust authorities and } \\
\text { divestitures were ordered. However, local market } \\
\text { concentration increased significantly in many markets. }\end{array}$ & $\begin{array}{l}\text { Merger of two large French } \\
\text { supermarket firms in } 2000 .\end{array}$ & $\begin{array}{l}\text { Rivals increased prices by } 1.5 \% \text { to } 2.5 \% \text { as } \\
\text { a result of merger. }\end{array}$ \\
\hline $\begin{array}{l}\text { Ashenfelter, Hosken, and } \\
\text { Weinberg (2013a) }\end{array}$ & $\begin{array}{l}\text { Estimates how prices increased in appliance } \\
\text { categories where merger raised concentration } \\
\text { relative to other categories. Compares } \\
\text { merging parties price changes to rivals. }\end{array}$ & $\begin{array}{l}\text { Merger reviewed by U.S. DOJ, but cleared without } \\
\text { conditions. The merger resulted in large increases in } \\
\text { concentration. }\end{array}$ & $\begin{array}{l}\text { Maytag/Whirlpool appliance } \\
\text { merger. }\end{array}$ & $\begin{array}{l}\text { New Maytag dishwashers: 5\%; New } \\
\text { Whirlpool dishwashers: Unchanged; New } \\
\text { Maytag driers: 5\%; New Whirlpool driers: } \\
\text { 13\%; New Maytag fridges: unchaged; } \\
\text { New Whirlpool fridges: 3\%; Clothes } \\
\text { Washers: Unchanged }\end{array}$ \\
\hline $\begin{array}{l}\text { Ashenfelter, Hosken, and } \\
\text { Weinberg (2013b) }\end{array}$ & $\begin{array}{l}\text { Correlates change in price with anticipated } \\
\text { change in concentration and reduction in } \\
\text { shipping distances due to merger across local } \\
\text { markets }\end{array}$ & $\begin{array}{l}\text { Merger reviewed by U.S. DOJ, but approved without } \\
\text { conditions. The merger reduced number of U.S. macro- } \\
\text { brewers from } 3 \text { to } 2 \text {. }\end{array}$ & Miller/Coors brewing merger & $\begin{array}{l}\text { Increases in concentration predicted price } \\
\text { increases, reductions in shipping distance } \\
\text { predicted price reductions. In average } \\
\text { market effects offset each other. }\end{array}$ \\
\hline $\begin{array}{l}\text { Bjornerstedt and Verboven } \\
\text { (2013) }\end{array}$ & $\begin{array}{l}\text { Estimates how prices changed before and } \\
\text { after merger absolutely and relative to a } \\
\text { competitor. }\end{array}$ & $\begin{array}{l}\text { Investigated but cleared by Swedish Competition } \\
\text { Authority primarily because of coming deregulation of } \\
\text { state-owned pharmacy monopoly. }\end{array}$ & $\begin{array}{l}\text { Merger berween AstraZeneca } \\
\text { Tica and GlaxoSmithKline, both } \\
\text { OTC analgesic producers in } \\
\text { Sweden. }\end{array}$ & $\begin{array}{l}42 \% \text { in absolute terms, } 35 \% \text { relative to } \\
\text { competing firm. }\end{array}$ \\
\hline $\begin{array}{l}\text { Guardado, Emmons, and Kane } \\
\text { (2013) }\end{array}$ & $\begin{array}{l}\text { Estimates how prices changed in state with } \\
\text { overlap (NV) relative to other areas. }\end{array}$ & $\begin{array}{l}\text { Authors searched for a merger with the potential to } \\
\text { facilitate the exercise of market power (a merger of large } \\
\text { insurers resulting in a large increase in market } \\
\text { concentration). }\end{array}$ & $\begin{array}{l}\text { Health insurer merger involving } \\
\text { UnitedHealth and Sierra }\end{array}$ & $13.7 \%$ price increase \\
\hline
\end{tabular}

